\title{
The grand experiment
}

SCIENCE in France is going for boom - or bust. The objective is to be the (socialist) Japan of Europe, and new technologies, founded on good science, will lead the way. What a contrast with the rest of the developed world. It is a great experiment, which deserves to succeed. Of course, along the way there will be many pitfalls, and in the next few pages an attempt is made to reach an objective assessment of the situation.

In fact, the experiment is not a new one. French science and technology returned to the centre of the world stage in the 1960s and 1970s thanks largely to the vision of General de Gaulle. According to figures collected by one of the present science minister's cabinet advisers, M. Pierre Papon, French science spending didn't just increase during de Gaulle's rule - it quintupled. In 1958, the French government spent FF1,540 million on research and development; and in 1967 (when de Gaulle resigned) the figure was FF8,836 million. Part of the rise can be accounted for by inflation, but even as a fraction of the government budget, the increase was staggering; from 2.5 per cent in 1958 to 6.2 per cent in 1967.

De Gaulle sought national independence, which among other things implied economic and military independence of the United States. There should be French nuclear weapons; French rockets; French electronics; French energy. And of course, French science both to support this technological development and, not least, to fly as a flag of French pride.

The experiment worked, in most essential areas (electronics still has a long way to go); and in the process science in France was transformed. There were 9,000 researchers in the state sector in 1958, and 21,000 in 1965. (The 1968 university revolution, which came the year after de Gaulle's departure, added even more: the figure was 31,000 in 1969.) This was the age of gold.

As if to confirm de Gaulle's investment, though no doubt entirely unconnected, the first of six Nobel Prizes won by Frenchmen since the war were announced in 1965: those of André Lwoff, Francois Jacob and Jacques Monod. Monod, however, gave a sour interview to the weekly newspaper Le Nouvel Observateur after his award, claiming that M. Georges Pompidou, de Gaulle's prime minister, was not doing enough for science. ("Pompidou never forgave him for that", says Jacob.) Perhaps it was true that more was being done for physics than biology, though one of those concerned with distributing the money in those days - M. Charles Thiebault, recently president of the Centre National de la Research Scientifique - says molecular and cell biology had a high priority in de Gaulle's programme. Thiebault's figures on French research productivity in the 1970s (see following page) show that the most dramatic increases in that decade came in molecular and cellular pharmacology, a fact which can be traced back, he believes, to increased support in the 1960 s.

But how long can such experiments last? By the 1970s, the gold had tarnished. De Gaulle had pushed the national French research and development effort, including industry, from under one per cent of gross national product in 1958 to 2.2 per cent in 1967 . Monod seems to have been right about Georges Pompidou, for when he became President the science budget began to fall. By
1980 , research and development spending accounted for only 1.8 per cent of the country's gross national product. French science during the 1970s was based largely on the structure and staff given to it by de Gaulle.

Today, the unlikely inheritor of de Gaulle's scientific mantle is the left-wing socialist $M$. Jean-Pierre Chevènement, not as president of France, but as minister of state for research and technology with his own powerful ministry (something de Gaulle, in fact, avoided setting up). Chevènement, strongly backed by President Francois Mitterrand, is in effect relaunching Gaullism for science - albeit with a human face. The difference is that Chevènement's programmes are being designed for the people; de Gaulle's were for "France". If the difference seems subtle, that's because it is subtle. There is only a touch of democracy in Chevènement's thinking. His is a planned economy. But it is one, at least, in which the impact of technological change on the fabric of life in France will be taken into account in the development of policies.

Also, and inevitably in 1982, Chevènement's choice of grands programmes differs from de Gaulle's. The new minister does not control defence research (which was 65 per cent of de Gaulle's first research and development budget). So physical science will not be so prominent. In fact, the most advanced and active of Chevènement's plans concern biotechnology, with its spin-off of support for molecular biology, microbiology and enzymology.

The 64 million franc question, however, is whether the plan will work at all. The whole economic exercise now under way in France is a gamble on investment: the exact opposite, say, of British policy. The projected budget deficit of the French government for 1983 is now FF 200,000 million ( $£ 20,000$ million). Moreover there are structural and psychological obstacles to the further development of science - and in particular, technology - in France. These centre around the strong, historic distinction that has been drawn in French higher education between training (represented by the grandes écoles) and culture (represented by the universities). De Gaulle probably went as far as he could without changing this system substantially. Chevènement, needing to go beyond de Gaulle's achievements, may not have that luxury.

\section{CONTENTS}

Has France got the money . . .

.... and the science?

Read right on from here

Great schools, great contradictions

The minister answers some questions

Science - the next revolution?

CNRS - the core of research

Medicine hot, agriculture cool

Biotechnology - gearing up

Telecommunications - late start

National trend in space

Taking a nuclear power lead

Superphénix - great white hope

Nuclear power - how committed?

Trebling renewable energy by 1990 


\section{Has France got the money .}

IT seems that France is now committed to an immense and breathtaking economic gamble, like a hardened punter throwing all his chips on one spin of the wheel. In direct contrast to the straitlaced grocershop monetarism now the fashion in Britain and the United States, the French solution to the recession, to unemployment and the challenge of Japan is to spend, spend, spend.

Consider the ministry of industry. Capital aid to industry and business excluding the defence industry and support for research and development - has grown 80 per cent this year to FF8,000 million ( $£ 800$ million). Against such massive increases in direct support to industry, the 29 per cent increase in the government research budget for 1982 looks almost niggardly. Moreover, the increase in spending money - as opposed to commitments to order, but not actually buy, equipment and materials - has risen only 23 per cent, or 9 per cent allowing for current inflation; and since the US dollar has risen 50 per cent against the franc in the past two years, and many materials and much equipment must be bought at dollar prices, some laboratories claim that they are at best maintaining their real level of expenditure. Furthermore, some 25 per cent of this year's new money may be with- held if the economy does not perform as hoped, so there are growing doubts among researchers as to the true value of the "boom".

Nevertheless, Jean-Pierre Chevènement, minister for science and technology, is giving major boosts to certain areas, which must survive the worst of disasters. ANVAR, the Agence Nationale de Valorisation de la Recherche, which seeks to convert research in university and government laboratories into productive industrial innovations, will increase its budget by 76 per cent this year; alternative energy research grows 50 per cent; and aid for the dissemination of scientific information, up 80 per cent.

Meanwhile the budget and foreign trade deficits balloon massively. The total government budget will increase by 28 per cent this year - leaving an estimated deficit of FF95,000 million $(£ 9,500$ million). The foreign trade balance (dominated by oil imports) is expected to be in deficit to about FF60,000 million ( $£ 6,000$ million). For rough comparison, Britain's current account deficit is about 10 times less severe, when oil revenues are subtracted. (Including oil revenues, Britain is in the black to about the same degree that France is in the red.) around: the Mitterrand gamble is a long one.

\section{. . . and the science?}

FrenCH science is on the move - upwards - according to figures prepared by the expresident of the Centre National de la Recherche Scientifique, Professor Charles Thiebault, with help from CNRS and the Pascal bibliographic data bank (see table).

Thiebault calculated the percentage of research papers of French (and other nonUS) origin in the 286 most-cited journals of Science Citation Index, and compared two years as near as possible to 1970 and 1980 . By this measure, all French science except physics increased in literature penetration during the 'seventies. The best single penetration at the end of the decade was achieved by French astronomy: in 1979, 10.8 per cent of the surveyed astronomy papers were French. The best improvement was in pharmacology, from 0.5 to 5.5 per cent. Most of the papers were in English.

By comparison, the United Kingdom suffered a dramatic decline.

As with all such figures, however, the data must be interpreted with caution. The number of French scientists leapt up during the expansion of the universities in 1968-71, so to some extent increased penetration is a measure of increased quantity rather than quality. For example, French mathematics is certainly far better than seems to be indicated by its penetration of the literature. Since 1945, the Fields medal for mathematics - the
"Nobel Prize" of the subject - has gone five times to France, compared with only eight to the United States (which has five times the population). By contrast, in the scientific Nobel Prizes, France has been weak: six since 1945 (two in physics, four in physiology and medicine) compared with 13 in Germany and 35 in Britain.

\begin{tabular}{|c|c|c|c|c|c|}
\hline \multicolumn{6}{|c|}{ Fraction of papers $(\%)$ in major scientific journals } \\
\hline Disciplines & France & $\begin{array}{c}\text { West } \\
\text { Germany }\end{array}$ & UK & Japan & Canada \\
\hline \multicolumn{6}{|c|}{ Mathematics } \\
\hline 1970 & 3.4 & 9.0 & 10.0 & 1.0 & 4.5 \\
\hline 1980 & 7.2 & 11.5 & 6.9 & 3.3 & 3.4 \\
\hline \multicolumn{6}{|l|}{ Physics } \\
\hline 1973 & 8.5 & 6.4 & 10.2 & 4.0 & 4.5 \\
\hline 1979 & 8.2 & 8.4 & 6.7 & 5.3 & 4.3 \\
\hline \multicolumn{6}{|l|}{ Engineering } \\
\hline 1972 & 4.5 & 4.7 & 15.5 & 4.6 & 5.6 \\
\hline 1979 & 5.9 & 5.5 & 8.8 & 8.1 & 4.2 \\
\hline \multicolumn{6}{|l|}{ Chemistry } \\
\hline 1970 & 2.9 & 3.7 & 16.2 & 5.9 & 4.2 \\
\hline 1980 & 7.3 & 5.8 & 10.5 & 8.8 & 4.5 \\
\hline \multicolumn{6}{|c|}{ Geophysics/Space } \\
\hline 1972 & 3.5 & 3.1 & 10.4 & 1.9 & 7.1 \\
\hline 1979 & 5.0 & 3.7 & 9.3 & 2.4 & 6.6 \\
\hline \multicolumn{6}{|l|}{ Biology } \\
\hline $1970-73$ & 2.3 & 4.6 & 16.0 & 2.8 & 3.9 \\
\hline $1979-80$ & 4.4 & 5.0 & 12.0 & 4.7 & 4.6 \\
\hline
\end{tabular}

Thiebault himself interprets the figures as a good broad measure of the productivity of the community of French scientists, indicating that France is now producing science "at the normal rate". But he is worried about what will happen in the late 1980s. Scientists are most productive in their $30 \mathrm{~s}$ and $40 \mathrm{~s}$, Thiebault believes, and the drastic fall in French recruitment of young scientists in the 1970s may ultimately show through in output.
Read right on

\section{from here}

IN the following articles, there is an Anglo-Saxon look at France in something approaching a logical sequence. But it may not be logical enough for a French man or woman. Logic is a great French strength, but also a weakness. The greatest respect goes to the most abstract disciplines: purest of pure mathematics, the most theoretical anthropology. The schools create this love of logic, and the grandes écoles foster it.

Logic is also linear, and the French certainly love the direct route. Crossfertilization and mobility seem to be foreign ideas. The author of a recent report recommending the establishment of an agency for technology assessment wrote "in France, there are traditional difficulties in thinking in terms of complex systems and networks . . ."

Careers also are seen linearly. A vogue word these days is filiere, which is usually applied to industry: a filière is a whole chain of connections which takes a primary material to its marketable product. There are filiere electronique, filière énergetique, and filiere what-youwill. Industry is a clutch of distinct filieres. It is the same with careers. One follows one's chosen career, with a series of qualifications marking progress and serving to attach one firmly to this line rather than another.

In the following pages, some of these threads are laid out: the line of the grandes écoles, which leads to industry and the ministries, and skims off many of the most able pupils; the line of the universities, still wavering after the "revolutions" of 1968, where most French research is done; and the line of the grands organismes, the big state institutions which fund and control the best of that research.

The new politics of research are outlined on page 299 - the minister for science, Jean-Pierre Chevenement, wishes to push French research and development spending up by 25 per cent in real terms by 1985 , to 2.5 per cent of the gross national product. Chevènement may be spending more money and employing more people, but he is also attempting to link a few of the stubbornly separated filières: to link industry with the grands organismes, research with the grandes écoles, thereby seeking greater productivity from French science.

At the same time, Chevènement will be creating some filières of his own: a number of full-scale national research and development programmes, after the style of de Gaulle before him. We sketch one: biotechnology (page 295). Finally, we review two of the most successful existing French technological programmes: space and nuclear energy. 


\section{Great schools, great contradictions}

THE most extraordinary thing about the French education system is that it is dominated by science, and yet it is inefficient at producing scientists. At the age of 14 , children are selected to study for this or that branch of the baccalauréat, or "bac". The most able are groomed for bac $\mathrm{C}$ : mathematics and physical science. To do anything else is, by comparison, to opt out of the academic race. Bac $\mathrm{C}$ pupils are virtually the only entrants to the grandes ecoles, the higher education production lines of the French élite. When bac C pupils go to university, as nearly half of them do, they do better than any other class.

Yet of this leading group, only a minority choose to study science. Have they had enough of it? Roughly one in eight go on to short-term technology courses at "instituts universitaires de technologie". Another one in eight (about 3,000 a year) study science at university. Two-thirds of those who go to university study something other than science.

The contradiction goes deeper. The really ambitious bac $\mathrm{C}$ pupil goes on to two-year preparatory classes, cramming schools aimed at the special entrance exam to the grandes écoles, the concours. The preparatory courses are called taupe (and hypotaupe) - that is, "mole" and "hypomole" - for good reason. The work is so intense that the student never lifts his or her head to the light of day. Once a student is successful in the concours, the grandes écoles themselves are a relaxation: a qualification and a good job are almost guaranteed.

What then do these moles learn when they emerge into the grandes écoles? Not "science", properly speaking. The teachers, on the whole, do not do research. There are great variations in coverage, and in quality, but what is called "engineering" dominates. Of 300 or so grandes écoles, 160 are engineering schools. Another 60 are business schools, and another 80 cover miscellaneous arts and occupations. Two or three schools do have substantial research departments, including the prestigious Ecole Normale Supérieure, and so teach science effectively - but only to a few hundred, in total, of the bac $\mathrm{C}$ élite. Moreover the science is almost exclusively physical; biology has until recently been largely neglected.

Even the engineering taught by the grandes écoles is said to be too theoretical, too dry and too dated to be good engineering (though there are important exceptions, of course). So what do the grandes ecoles teach their students? They teach rigour in argument, and - a practical matter - how to take decisions.

The subjects studied might as well be classics for all the significance they have. The jobs pages of Le Monde, the principal French newspaper, are plastered with adverts for ingenieurs grandes écoles not because these are engineers, but because these will be the most intelligent managers. The ministeries of the French state also recruit most of their top staff from the grandes ecoles.

The remarkable result is that while French education stresses science from the age of 14 , the product is a group of managers and civil servants who could hardly be further from research. The university system, where research is done, is seen very much as second class, and the social distinction is maintained throughout life. The club of the grandes écoles is exclusive, and the damaging consequence is that research penetrates industry far less than it should.

The universities themselves have their own problems. They were not ready for the student population bulge of the sixties, and together with certain social and political factors the result was the transformation of 1968, whose impact has still not been properly assimilated.

The rise in student numbers was dramatic. In 1960, there were 223,000 students studying in the French universities - which were then arranged as almost totally independent, unconnected faculties specializing in this or that discipline. By
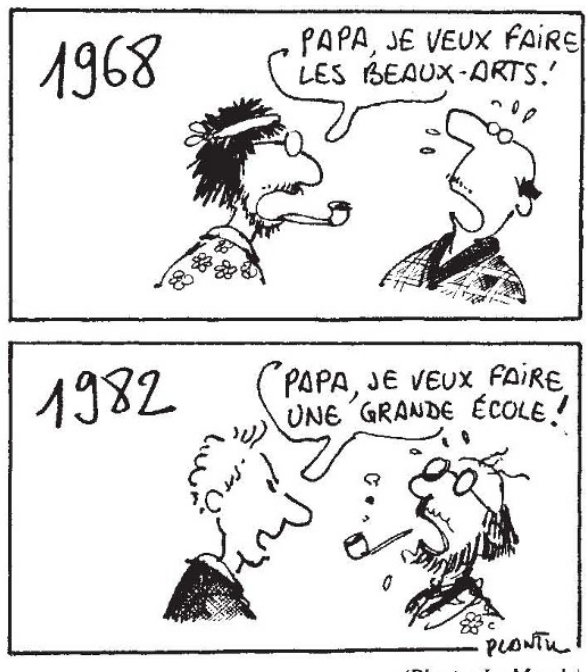

(Plantu, Le Monde)

1968, there were more than 575,000 students cramming into the same lecture halls. "Often there were hundreds at a lecture", wrote one observer, "many of them sitting on the floor right up to the blackboard. Students had to arrive early to get a place"'. The chalky lectures seemed out of touch with the concerns of youth: the Vietnam war, alternatives to "scientism" and economic growth. The students demanded change, and got it.

The present French universities, apart from ancient establishments like the University of Paris, are largely the creations of 1968. Faculties were grouped into multidisciplinary campuses. Students were given rights in university administration, new courses started, new

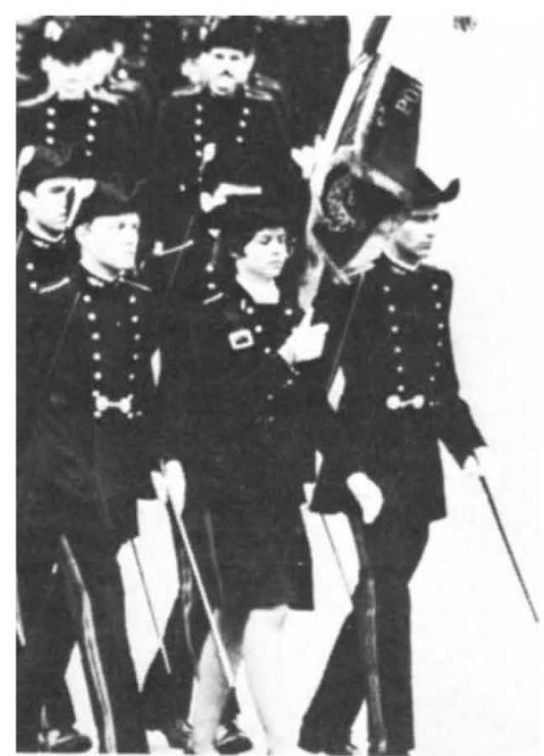

First lady at the École Polytechnique: Anne Chopinet graduates in 1972, one of a group of seven who were the first women ever to study there. Now she deals with mineral resources and uranium exploration at the ministry of industry.

universities founded, and new lecturers recruited. Recruitment had been going on earlier, however. In 1960, there were 10,000 university teaching staff from professors through maîtres conference, maîtres assistants, to assistants. In 1967-68, the number had reached 26,000. Some 2,000 assistants were recruited that year. But in 1968-69, the number of appointments was 4,500; in 1969-70, 2,500; and in 1970-71 (slowing down substantially) 800 . By 1973-4 the number of teaching staff was nearly 41,000 (where it has roughly remained for ten years). Thus in 1980 there were 41,000 lecturers and 861,000 students, a university system almost exactly four times that of twenty years before, containing a mass of assistants created in one brief five-year period. Throughout this higher education boom, the grandes ecoles remained aloof, taking almost constant numbers.

The suddenness of this growth, and the continuing strong position of the grandes écoles, has meant that the universities have found themselves almost entirely detached from the centres of power in France, from industry and from government (which nevertheless keeps them on a tight rein, like an errant child). There has thus grown up a feeling - in part a legacy of 1968 - that the unversity and its research should not be sullied by contacts with industry. This has become a principle, one which also gives the new university system a feeling of dignity in French life.

The distinction is even reinforced by law: university staff are civil servants who, in principle, should not seek consultancies in industry; and the universities should not enter into any kind of profitable liaison with a company. Needless to say, the more enterprising universities and staff have set up such links by devious means; but the law sets up obstacles. (One of the most important exercises undertaken by the new 
minister of science, Jean-Pierre Chevènement, therefore, will be to remove these legal trip-wires, and the forthcoming "law of research"' (see page 289) should do so. But the established suspicion of industry will remain.)

There is also another weakness in the French university system: its relation to research itself. The control and management of French science rests essentially with the grands organismes, roughly equivalent to other countries' research councils, but more powerful and paying more salaries. The grands organismes draw their researchers from the university system, give them better research facilities, remove their heavy load of teaching and administration but - for the moment - give them worse conditions of employment: lower pay and fewer rights, even though they may be working in the same campus, even the same laboratory as university "teacher-researchers".

Most scientists, however, are keen to make the deal - as is evidenced by the nearly eight-to-one ratio of applicants to posts at the junior grands organismes level of attache (see page 287 for details of the more prominent grands organismes). The grands organismes, plus one or two separate research institutions like the Institut Pasteur (biology) and the Institut des Hautes Etudes Scientifiques (mathematics and theoretical physics) are the heart of science in France.

Now comes the crunch: since grands organismes researchers tend not to teach,

\section{France's big spending research organizations}

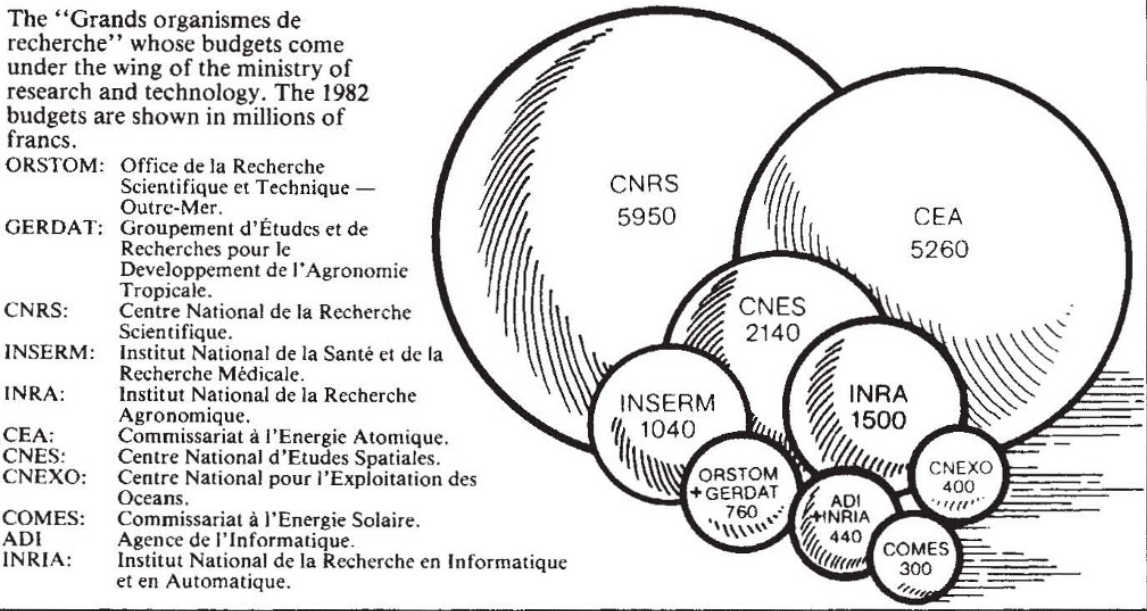

and since they do the best research, higher education is denuded of its leading scientists. So how are scientists trained?

This may become one of the most important issues in French science policy, for with the promised civil servant status for grands organismes researchers, matching that for university teachers, there will be nothing to keep researchers in the lecture theatres but a dedication to teaching. Much is now being made of the catch-phrase "education for and through research", but the means are still being sought to bring it to reality. The grands organismes are now under pressure to play a greater role in education, and they must take it up if they are to find the scientists they need in future years - but the universities are very wary of such moves. seeing them as an encroachment on the territory.

All in all, there is a lot to be done. The government does seem to be aware of the problem: the minister of education, $M$. Alain Savary, promises a new law for the universities by the autumn, and he is working in close collaboration with his pushy opposite number in the ministry of research, Jean-Pierre Chevenement. We shall see then if anything substantial and long-lasting is to be achieved with French science.

\section{What Aigrain thinks of it all}

THE man who must look most wryly at the present efforts to create a renaissance in French science and technology is Pierre Aigrain, now director of research and development at Thomson CSF, but minister of science under Giscard d'Estaing.

Wryly, because he had begun to push up the science budget in 1981 (not so much as Chevènement in 1982, but the latter's efforts are carried on the tide of an overall 27.6 per cent increase in government spending). Wryly, because the politics of opening science to industry were his own. In some areas Chevenement has even taken on the very advisers that Aigrain used. Chevènement appears to be getting the glory for a policy which, in large part, was established by Aigrain. So what does he think of his successor's plans?

Aigrain is "very glad" about the proposal for a law that would more or less guarantee the science budget for a few years (see opposite). But otherwise he feels there has been a change of wording more than a change of substance. Aigrain clearly thinks that the National Colloquium on science and technology, which drew together scientists and others influenced by their work in a great jamboree of meetings late in 1981 and early this year, was a marvellous idea, for the real problem of development in France is a matter of psychology as much as one of regulations and budgets; the colloquium demolished some barriers.

However, he is worried about Chevènement's accelerations of scientific recruitment to the grands organismes

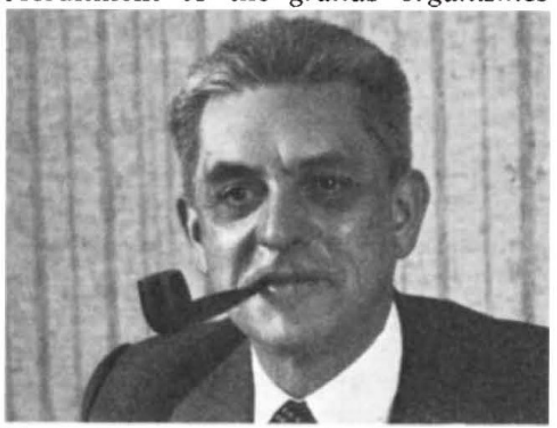

Pierre Aigrain - pleased with the "loi programme" but worried about industry

(like CNRS) from 3 per cent of staff per year (under his ministry) to 4.5 per cent. There are enough good people to fill the quota, says Aigrain, but not enough left over to satisfy the needs of science-based industry; and since the security and terms of employment in the grands organismes are excellent, industry is going to have a hard time reaching the 8 per cent a year real growth in research and development demanded by the new minister.

Education needs an overhaul, and the government is aware of the problem, Aigrain believes, but an education system has a lot of inertia. Moreover, the source of the problem lies in the secondary schools, so change effected there will take ten years to have an impact on research.

The secondary schools overstress the mathematical and physical sciences, are too abstract, and demand too much of their pupils, he says, "so people who would have been quite good physicists and electrical engineers turn to biology to avoid the 'terrorist' attitude of our mathematicians". The result is too many biologists and far too many social scientists.

The grandes écoles, the majority of which teach engineering, also have a lot of drawbacks. They are rather small, and so produce too few engineers. On the other hand, the universities have completely neglected to train people for industry, and although good research is done, little of it is relevant to industrial problems. "What should be done is to improve the university system and its links to industry, and the selection of university students", Aigrain concludes. Judy Redfearn \& Robert Walgate 


\section{No union dominance at the CNRS}

\section{The minister answers some questions}

THE new politics of research and development in France raises many questions, but some are particularly troublesome. How far will Jean-Pierre Chevenement, research and technology minister, go along with trade union demands for democracy in the laboratory? Why does he insist on the importance of French as a scientific language? And finally, what can he do about getting more scientists into industry?

The first question is particularly topical, for the scientific trade unions in the Centre National de la Recherche Scientifique (CNRS), the leading basic research institution in France, have buried their differences to demand union, and only union, representation on the Comité National - the all-important "parliament" of CNRS (see "Pressing problems for Payan", page 293). What does Chevènement think of that Robert Walgate asked him?

The minister says he is at pains to preserve the "effectiveness and openness" of the Comite National, which must play a greater role than before in determining the policies of the CNRS. But he added that although there would be "no question" of giving a monopoly of seats to the unions, the seats should be open to the unions (through election). It would also be a good thing, says Chevènement, if the unions began to concern themselves more with "the quality of research" in their politics, a remark that indicates that he would like the union to broaden their horizon. Nevertheless, says the minister, a union presence "raises the level of debate".

As for promoting the use of French in science, Chevenement says the objective is to help communicate science to the public, and to those who might make use of it in industry, "to maintain the strict link between the French scientific community, and the national community, which would be put under great strain if French ceased to be the language of scientists ... French must be defended even in areas of research where the rule is to use English."

It follows that all French research must be published "at least" in French and, "if possible", in other languages, says the minister. In conferences held on French soil, French must be one of the working languages. A long-term programme must be undertaken to "renew French scientific and technical publications". A government supported publishing house will be set up for this purpose, says Chevenement and there will be "a vast effort" to translate foreign publications into French.

Many have claimed that the cost of such

a programme will make it impractical, but "it will not cost as much as they say" says the minister. The budget for the programme this year is FF 70 million ( $£ 7$ million). But Chevenement adds that this budget is planned to grow "considerably" in the years to come.

Finally, research in industry will be supported by plans to train 1,500 engineers a year "through research" by 1985 , compared to only 500 a year at present. (France produces some 11,000 qualified

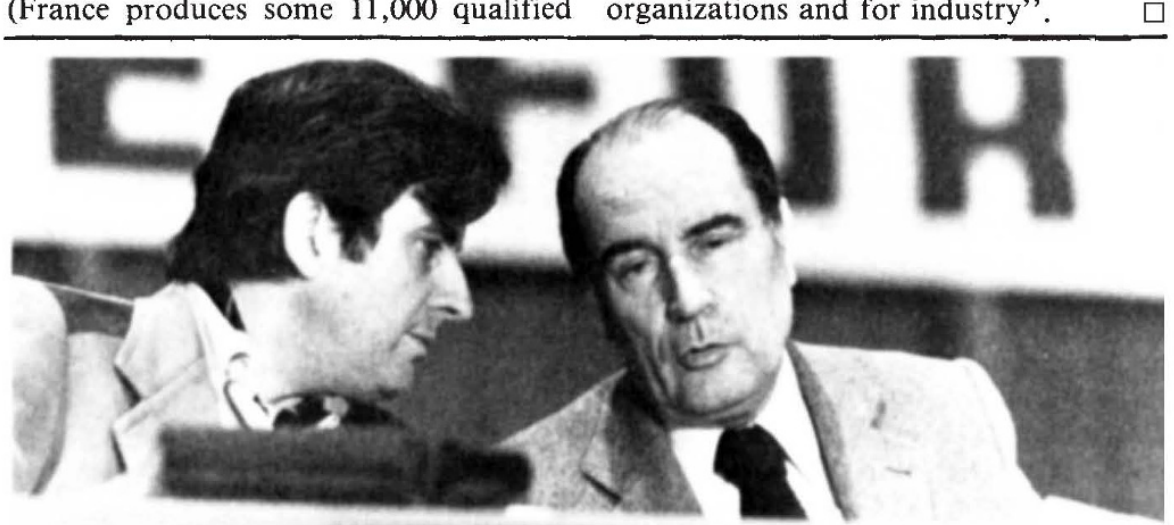

"Make France the third scientific and technological power of the world" François Mitterrand (right), President of France, has told minister of state for research and technology, Jean-Pierre Chevenement (left).

\section{A new law for science}

ONE law for the military, one for science: the management of the defence budget was foremost in the science minister's mind when he created a "programme law" for science which would define the budget and orientation of his ministry for five years. The ministry of defence employs a series of such laws, which avoid the frequent battles for funds and policies.

The result is the "loi de programmation et d'orientiation", now before the French economic and social committee for comment and possible amendment. The law fixes a government civil research and development budget increase of $\mathbf{1 7 . 8}$ per cent a year in real terms, averaged over the three years covered by the law. Fundamental research gets a 13 per cent per year increase. Jobs in science will be created at the rate of 4.5 per cent of existing positions a year (on average). And support will be given to industry to increase research budgets by 8 per cent a year.

No details are given in the law of how the money is to be spent, which has been taken by some to be a weakness; on the other hand, the ministry sees this lack of detail as a strength, giving it room for manoeuvre.

Moreover, one major financial battle has already been won: in the section on grands organismes the law speaks of financial control a posteriori. Up to now the ministry of finance has held very tight rein on the details of budgets with laboratory directors consequently unable to make even minor changes in spending engineers a year at the moment, but only a small fraction have training in research.) Particular efforts will be made to train the engineers and scientists needed for the programmes mobilisateurs - the special longterm programmes of the ministry, such as biotechnology and electronics. "This is in line with a major policy of training through research that we think will resolve the problems of high-level scientific recruitment, both for the public research organizations and for industry",

once the budget for a year has been agreed. Under the new law, there should be more freedom.

This most important section of the law also redefines the role of the grands organismes. They would now have four tasks: to pursue research in every domain; to ensure discoveries are brought to application wherever possible; to spread knowledge; and to educate and train people "through and for" research. The law would also give the grands organismes a better legal framework in which to cooperate with industry. This would allow CNRS, for example, to join with and even hold shares in sister companies.

Researchers in the grands organismes, however suspicious they might be of industry should welcome the provisions in the law for a new contract of employment which would give them something approaching civil servant status.

Other important provisions in the law are an emphasis on regionalism and an identification of the main programmes of research to be developed by the ministry. These are: the rational use of energy and new sources; biotechnology; electronics; research in cooperation with and for the Third World; research on working conditions and the impact of new technologies; the promotion of French as a language of science; and technologies related to French industrial development not included in the above (with the exception of nuclear engineering). 


\section{Science - the next revolution?}

THE Mitterrand government wants to make its mark on history. So for what will we remember the minister of state for research and technology, Jean-Pierre Chevenement?

Quite likely for what the newspapers dubbed the "States General" of science, an apparently formless meeting in January this year of some 3,000 French men and women representing almost every nook and corner of French science and technology. This National Colloquium on Science and Technology was merely the culmination of a large series of regional meetings - the Assizes Regionales which took place the previous October and November, and generated 200,000 pages of detailed, local, reports and criticism on the management of science in France.

Why "States General"? Les ètats generaux were a feudal institution, last used by Louis XVI in 1788, in which reprentatives of all the parishes of France were called to Court to make their concerns known to the king. Louis himself misjudged them. The States General of 1788 raised such hopes that they led directly to the French Revolution of 1789.

So the National Colloquium of 1982 was a "States General" of science. That's not to suggest that next year there will be a revolution - but great hopes and fears have been raised among the scientific masses, and Chevenement now has to ride this flood or be submerged. Already certain trade unions, strong in French science, are threatening a struggle (see below). Whatever happens to Chevenement, he will be remembered for having created the National Colloquium. Pierre Aigrain, Chevènement's predecessor as individual views. most brilliant", said Lliboutry. minister of science, clearly regrets that he did not think of the idea himself. . .

So what are the main currents at work? It's not possible here to do justice to the 200,000 pages which are the main force of the colloquium. But here are a few

Take Professor Louis Lliboutry, for example, a world-renowned glaciologist with a position at the University of Grenoble and a laboratory supported by the Centre National de la Recherche Scientifique, (the major basic science organization in France). His subject is not one of the current fashions; glaciology does not have much impact on technology and the French economy; the laboratory is away from the centre of power in Paris.

Yet Grenoble is an excellent place to do glaciology, says Lliboutry - he can be at Mont Blance in an hour by car - but he felt this subject had been neglected by CNRS. "Our budget increases have not kept up with the cost of living", he said: and whileı the real money had shrunk, CNRS had shifted more and more resources out of the general budget and into special programmes, the Actions Thematiques Programmees (ATP). So in the past if your research did not fall within the framework of an ATP, you were neglected. In fact the exercise of raising cash had become largely one of convincing the relevant committee that your research fell within this or that ATP. For glaciology, one could sometimes make contact with the physics of tectonic plate movement or climatology, for example. "The people in the committees are the most noisy, but not necessarily the

There is an alternative now, however, on

\section{Colloquium into law}

PIERRE PAPON (right), professor of Iphysics in the University of Paris, is a prominent member of the science minister's cabinet. Papon was responsible for assessing the sometimes diffuse results of the National Colloquium on Science and Technology, and putting these conclusions into effect in the new law for science (see page 289).

Papon identifies four principal effects of the colloquium on the law: on regional development (regional councils for science were proposed at the colloquium, and have found their way into the law); the principle of education through and by research - which is to say that the grands organismes should have a role in education as well as the universities; other improvements in the training of scientists; and the recognition of research as a career so a researcher could expect similar conditions of employment in different organizations, to allow more mobility.

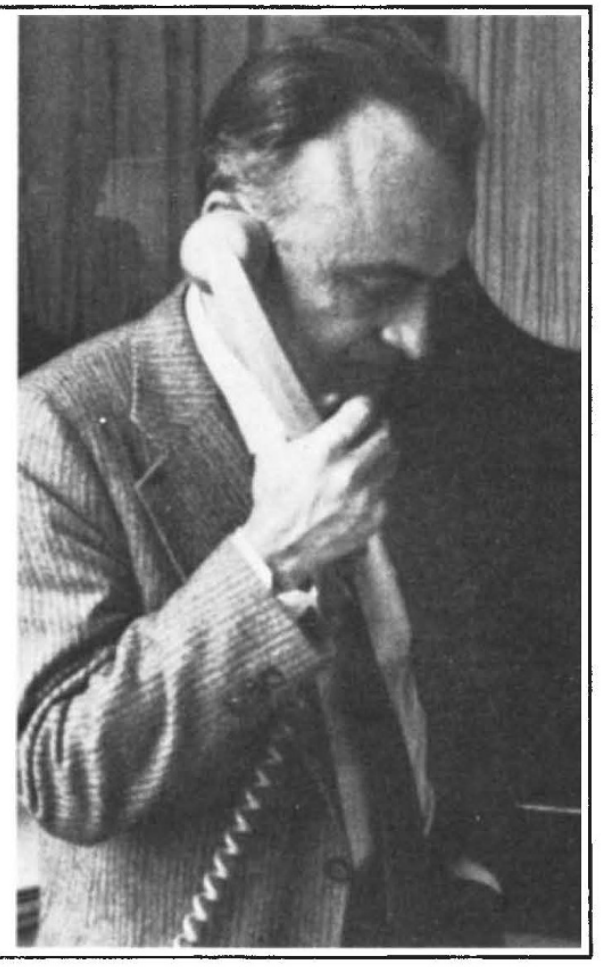

the ATPs - whose use increased greatly under Giscard d'Estaing's science minister, Pierre Aigrain. That's that they provide an opportunity for new researchers and new groups to draw on CNRS funds, in competition with established laboratories.

Unfortunately for Lliboutry and other laboratory directors who share his views, the emphasis on ATP increases slightly under the new government: CNRS funds for ATP rise $\mathbf{4 1 . 5}$ per cent this year compared with last. General programme support in CNRS will also rise, but less strongly: 36.8 per cent. Funds for big equipment (costing more than FF $100,000-£ 10,000$ ) increase least: 10.5 per cent.

However, another of Liboutry's worries may be dealt with by the research "law", the "Loi de programmation et d'orientation"' (see page 289 ) which is currently receiving the attention of the economic and social committee of the French Assembly. The problem is flexibility in the use of funds.

"We lab directors have no free money" says Lliboutry. This is the real obstacle to good research - what Lliboutry calls "the Kafkaesque rules for finance". These are imposed by the Ministry of Finance, but also by CNRS itself. For example, suppose Lliboutry asked for FF 100,000 for glaciology equipment and another FF 100,000 for general research expenses, for a project within some ATP; and suppose that ATP committee awarded only the latter FF 100,000 but ignored the equipment request. Then Lliboutry could not divide the sum 50:50 as he might wish.

This might change - at least in so far as the Ministry of Finance is concerned - if the lo $i$ is passed by the assembly, for the law will loosen constraints of this kind on CNRS. How far CNRS will choose to devolve this new freedom to its laboratory directors, and how far it will want to keep control through its central committees, is undecided, however.

Jean-Jacques Payan, the recently appointed director-general of CNRS, would in fact be well-advised to devolve this new power (if, of course, the Assembly approves it). Lliboutry's complaints are far from unique; they represent a widely-felt unease in the regions of France that the control of science has always been too hierarchical, too Paris-based, and that the minister for science, Jean-Pierre Chevenement, while paying lip service to "democracy", has in fact such wellformed plans that Paris control will continue as strongly as before.

"We need a local esprit d'enterprise in small science, with the freedom and the power to make judgments locally", Lliboutry suggests, with decisions up to a certain level taken by local laboratory councils. Many speeches and papers at the Assizes Regionales and the National Colloquium made the same or similar points. The loi, it seems, will set up regional science committees charged with esta- 


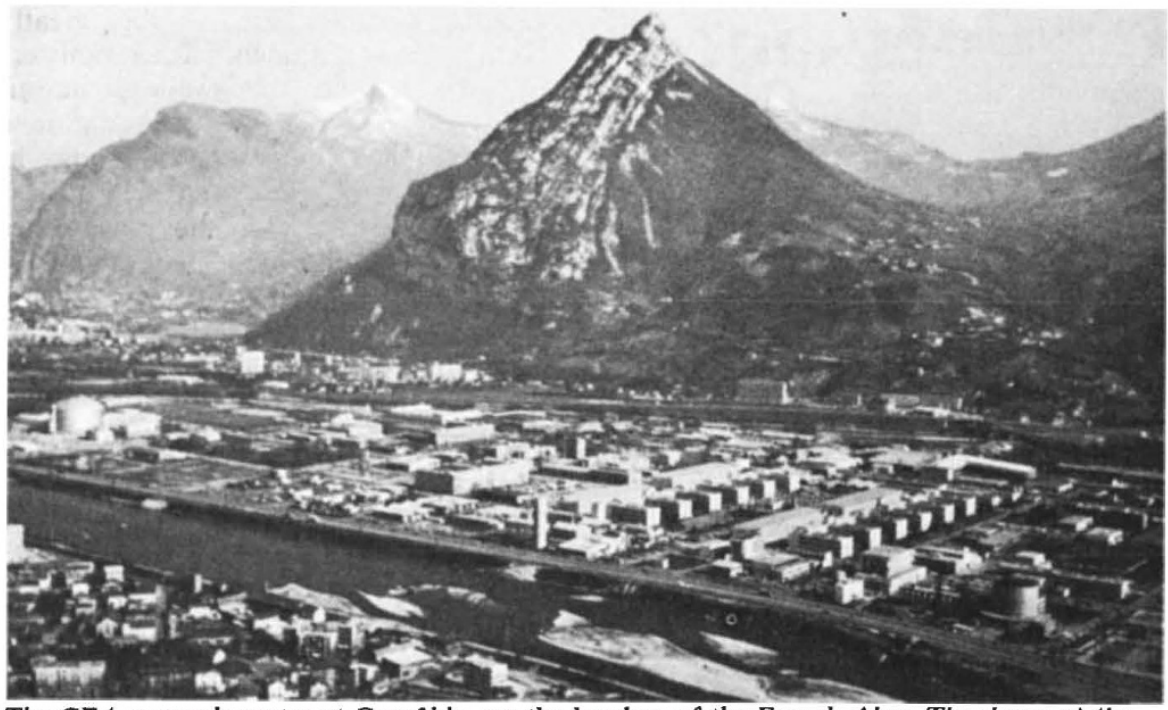

The CEA research centre at Grenoble, on the borders of the French Alps. The dome of the Institut Laue Langevin reactor building can also be seen on the left. The area includes many important laboratories and represents the largest concentration of physical science in France outside the Paris region.

blishing regional science policies and spending a certain amount of money, but it is unlikely that these bodies will have much effect on basic science.

The opposite concern - expressed at the other end of affairs, in Paris - is that there is a degree of rigidity in the system of science management, caused in part by the existence of laboratories whose directions are difficult to shift. Although in principle research posts with the big three research organizations - CNRS, INSERM (for medical science), and INRA (for agriculture) - are contractual, and assessments of performance of staff at laboratories are made regularly, laboratories are very rarely closed down and people almost never fired. Professor Charles Thiebault, who resigned last year as president of CNRS over a conflict with science minister Chevènement, says that of the 1,200 or so CNRS laboratories (one third of all university laboratories), perhaps one or two were closed each year and staff were moved on to new work. Moreover, a new contract for all research workers, contained in the loi, will give researchers even more security, matching that of civil servants.

Professor Michel Petit, director of INAG, which is effectively a wing of CNRS concerned with managing astronomy and geophysics, points to another stiffness in the joints: applicants for CNRS posts specify which laboratory they wish to join. So although assessment is made nationally, keeping standards up, students tend to return to their old professor's laboratory, reducing mobility.

These are directors' complaints, however. Down at the grass-roots, some rather more anarchic notes are being struck. At the Strasbourg Assize Regionale, for example, there was a strong call for laboratory directors' posts to be made fixed term - perhaps four years - to stop one man gaining lifetime control over a sector of research, and allow a few new flowers to bloom occasionally.

Even at the Institut Pasteur in Paris, a world-renowned centre for microbiology revolt. Laboratory directors should be continuously assessed, some of the younger researchers say. There is a directors in France to stop doing research and become full-time politicians, they complain - quite unlike the United States, where group leaders might spend time rooting for money but do not neglect the life of their groups. Jacques Monod, the famous director of the Pasteur in the late 1960 s and early 1970 s, is said to have been an exception. Certainly François Gros, the previous director of the Pasteur, has taken the political path: he is now science adviser to the Prime Minister, Pierre Mauroy.

The myth of the "savant", the wise man to whom all possible respect is due, is also too strong in France for the health of science, young researchers say. Strangely for the country which once slaughtered its aristocracy, there is an almost servile respect for these intellectual aristocrats.

According to Professor Bernard Jacrot - himself a potential savant, who directs the neutron scattering outstation of the European Molecular Biology Laboratory at the Institut Laue Langevin, Grenoble the problem starts in the secondary schools. "As soon as a pupil tries to be individual, he is stamped on" he says; and this reflects itself in the structure of the French laboratory, which is very hierarchical "leaving little room for originality".

Thus there is a need to give younger researchers their head, perhaps against the will of the all-imposing director, and this is a theme which the powerful French scientific trade unions have taken up with enthusiasm. But there is a difference between flattening the pyramid a little, and turning it upside down.

However, one of the clearest democratic and molecular genetics, there is a degree of tendency for group leaders and laboratory

\section{Big physics}

THE Commissariat a l'Energie Atomique (CEA) has a civil research budget for 1982 of FF5,260 million, exceeded only by that of the Centre National de la Recherche Scientifique. The budget is high not so much because the CEA supports a lot of researchers (nearly 9,000 at CNRS, only 900 in fundamental research at CEA), but because the bulk of CEA research is in the applications and development of nuclear energy. The fundamental science is also expensive - reactor physics, accelerator physics, nuclear fusion and high energy astronomy. However, CEA researchers also work in condensed matter and materials science and chemistry and biology (using isotopes). The fundamental research budget of the CEA in 1982 is FF 1,292 million.

The CEA works in strict liaison with the other grands organismes on many joint programmes (such as the nearlycompleted nuclear accelerator GANIL, in conjunction with $\mathrm{IN}_{2} \mathbf{P}_{3}$ ) and with international organizations such as the European Centre for Nuclear Research (CERN) and the Institut Laue Langevin. Its principal research centres are at Saclay, Caen, Fontenay-auxRoes, Grenôble, and Cadarache.

indications of the wishes of basic scientists has come from an internal survey conducted by CNRS. Professor Guy Aubert, director of the Service National des Champs Intenses, was charged with collecting the contributions of CNRS staff to Assizes Regionales and related meeting throughout France. Five main themes emerged, said Aubert.

First, people were worried that Mitterrand's and Chevènement's committment to regionalism would mean that peer assessments and appointments would be made and decided regionally. This was thought to be a bad thing, because a critical mass of assessors could not be reached and local savants might become even more influential.

Second, there was strong pressure for more "democracy" in the laboratory the banner which the unions are flying. There should certainly be consultation through a laboratory council, including administrators and technicians, over major developments. And there should be elections "even, and perhaps especially, of the laboratory director"'(Aubert sums up).

Third, it was felt that there"was more room for research in the social sciences not just more money for the field, but a reorientation of priorities towards current political, economic, and social concerns in France. This view is certainly shared by Chevenement, as the resignation of Charles Thiebault (mentioned above) as CNRS president was the result of the 
minister's efforts to force a social scientist of exactly this persuasion onto CNRS, as social sciences director.

Fourth, there was much puzzlement over the role and relationship of all the big organizations which control and fund science in France. "It seems to people in the laboratories that these things are not clear" says Aubert. It is possible to obtain money for a given subject from many different sources, under different rules, and career requirements under different heads for essentially the same work can be quite careers and priorities, and a reinforcement of the feeling that policy is decided behind closed doors according to unknown rules. Chevenement has said he seeks "transparency".

The situation seems to be most extreme for the medical sciences, and basic sciences bordering on medicine - going as far as molecular biology. Here there are the CNRS, whose major sector is life sciences; INSERM, the Institut National de la Santé et de la Recherche Médicale; the Mission de la Recherche of the Ministry of Universities; the universities themselves; and the teaching hospitals. Dr Jean Dausset, for example, is at the Hopital St Louis in north Paris. He is also head of an distinct. This leads to a confusion of

INSERM unit. And co director of a CNRS laboratory. Or take Professor Pierre Chambon. $\mathrm{He}$ is a professor at the Université Louis Pasteur in Strasbourg, and head of an INSERM unit and director of a CNRS laboratory, under the same roof. It is good to know that the new director of INSERM, Professor Philippe Lazar, and the director of life sciences at CNRS, Professor Roger Monnier, aim to resolve the issue.

The fifth and final concern detected by Aubert's review of CNRS papers to the colloquium and its tributaries was over the matter of contracts. As one foreign observer and francophile put it, the urge for security is extreme in France (so the trauma of two million unemployed can be imagined). So unions have been pressing, essentially, for tenure, and a strict demarcation of jobs; conditions of work like those of civil servants (the goal, it seems, of every Frenchman and woman); and an "open" assessment of researchers.

Some of these demands the unions will achieve in the "loi"; others they will not. But the unions are pressing harder on this left-wing government than they did on the previous right wing one, much to the socialists' embarrassment; and what the result will be is anyone's guess.

\section{CNRS - the core of research}

THE Centre Nationale de la Recherche Scientifique (CNRS) has FF 6,000 million to spend this year - about $£ 600$ million, including salaries. CNRS attracts and controls the cream of most basic science in France - with the exception of mathematics, which has a very strong French historical tradition and leads a more independent life. With that exception, the goal of most aspiring basic scientists in France is to join a CNRS group or laboratory - a goal which has become even more attractive now, since the new government has increased scientific recruitment to CNRS and its junior partners by 50 per cent, and now that CNRS scientists are promised essentially civil service security, pensions and other rights.

Entry to CNRS is by examination and interview. In 1980, for example, around 3,000 young scientists applied to join CNRS. Most of the 3,000 had just completed a troisieme cycle (something between a master's and a PhD degree) at a university; 425 of them were selected as attaches on a four-year trial, after which, according to the 3 per cent recruitment then in force, some two out of three might have expected to receive a full-time appointment as charge de recherche. With 4.5 per cent recruitment, possibly all of this bunch will be lucky.

CNRS now employs 23,320 people, of whom 8,970 are researchers, distributed in more than 1,200 laboratories. More than 150 laboratories are fully controlled by
CNRS (laboratoires propres), and another 250 shared with another organization, often a university (laboratoires associes).

The laboratories are distributed all around France, but by far the largest single geographical group is formed by Paris and its immediate locality - something which simply reflects the unusual dominance of the capital city of France over the rest of the country, in all sectors of life. However, CNRS has set up regional administrations, with a certain degree of power, and the new government is making an effort to identify new research "poles" outside Paris - or dominance of Paris in research. Here the area of the white circles represents number of CNRS researchers.
A graphic demonstration of the

\section{strengthen existing ones.}

It is perhaps unfair to make selections, but some of the outstanding regional centres are Grenoble and Lyons (for physics), Strasbourg (molecular genetics), Toulouse (biotechnology and space science) and Marseilles (immunology). The unique technological University of Compiegne - it can probably be counted just outside the Paris region - is also outstanding in enzymology, particularly as it relates to biotechnology.

The largest sector of the CNRS budget for 1982 goes to life sciences ( 25.5 per cent), which looms larger than it might because some of the heavier expenses of big science are borne by or shared with the Commissariat à l'Energie Atomique (for nuclear physics) or the Centre National d'Etudes Spatiales (for satellite-borne astronomy). Even so, life sciences are also supported by the Institut National de la Santé et de la Recherche Médicale - whose budget exceeds that of the life sciences sector of CNRS though employing fewer researchers.

Other sectors of CNRS are chemistry (15.7 per cent of the 1982 budget), nuclear and particle physics (12.9 per cent), earth, atmospheric, ocean and space sciences (11.8 per cent), mathematics and basic physics (11.7 per cent), social sciences ( 8 per cent), physical sciences for engineering (7.9 per cent), humanities (5.5 per cent), and interdisciplinary programmes (1 per cent).

CNRS is in fact organized as a "group" of three bodies: CNRS proper, plus INAG and $\mathrm{IN}_{2} \mathrm{P}_{3}$. The latter are the Institut Nationale d'Astronomie et de Géophysique, and the Institut National de Physique Nucléaire et de Physique des Particules, and they manage the parts of the total CNRS budget concerned with those fields. INAG and $\mathrm{IN}_{2} \mathrm{P}_{3}$ are loosely controlled by the CNRS directorate, which selects the INAG and $\mathrm{IN}_{2} \mathrm{P}_{3}$ directors (from lists of "at least two" names proposed by these bodies) and channels funds to the two

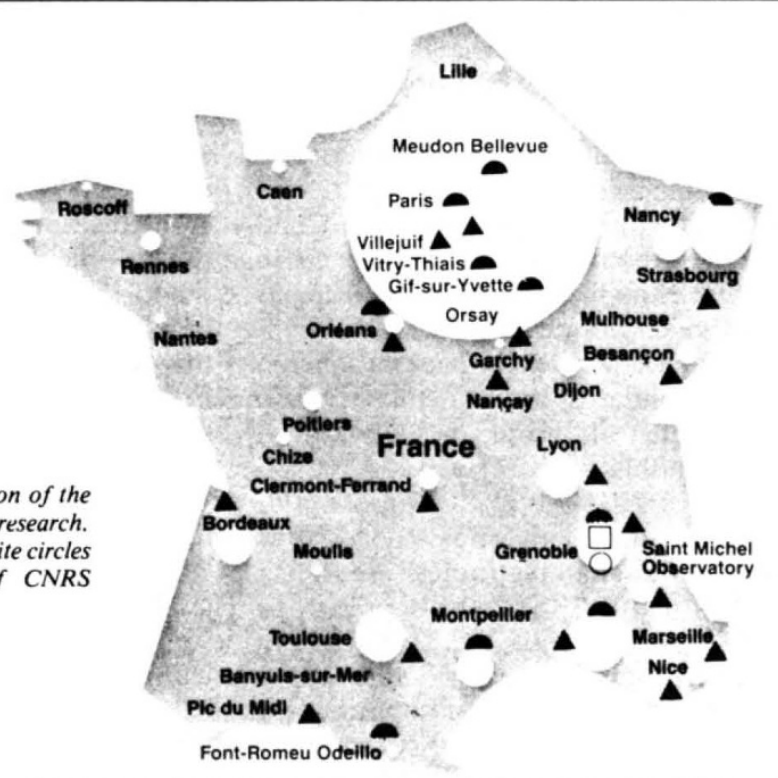




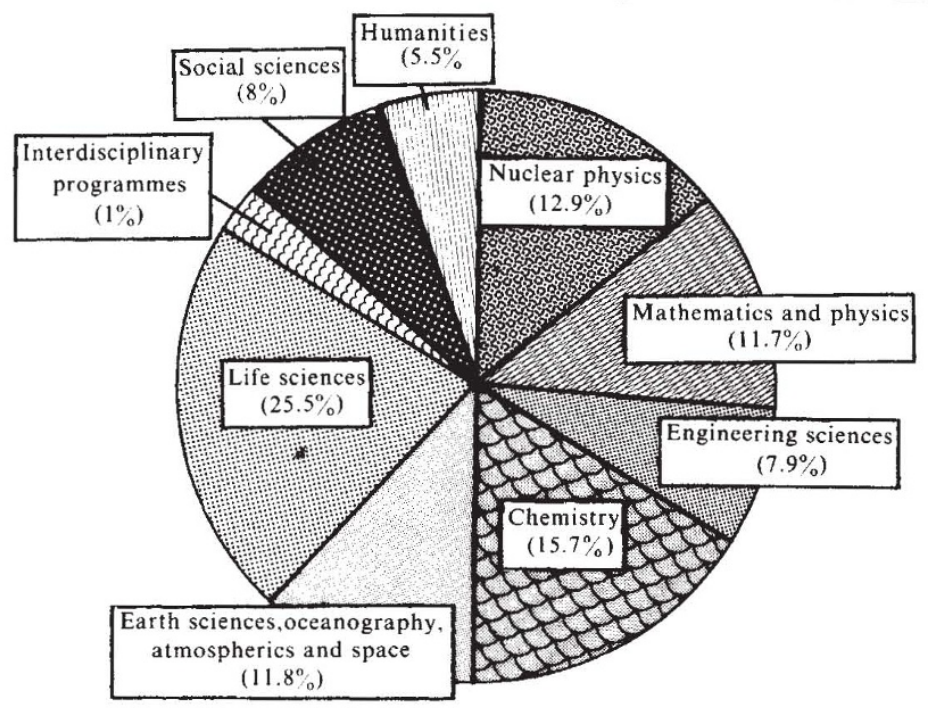

How the 1982 CNRS budget is being divided up. Life sciences get the lion's share. "Big science" is not as prominent as might be expected as budgets are shared in these subjects with CEA and CNES.

bodies. This year INAG receives FF 115 million, $\mathrm{IN}_{2} \mathrm{P}_{3}$ FF 576 million from within the CNRS budget. The structure is said to make the management of "big science" easier; certainly, battles over funds for expensive equipment are fought at a higher level in the CNRS hierarchy than might otherwise be the case.

The total CNRS group budget of FF 6,000 million represents an increase of 25 per cent over last year, a general increase which hides even larger rises in some sectors. General programme support and small laboratory expenses has risen 36 per cent from around FF750 million to over FF 1,000 million. Salaries take the biggest single chunk: FF 3,900 million. Increases over 1981 are smallest for large equipment and computers (just over 10 per cent). Against these increases weigh the current inflation figure of 14 per cent; the increase in the dollar against the franc (up 30 per cent over 1981); and the freeze on FF 150 million of CNRS funds (its share of the 25 per cent new money freeze - see first story).

New posts have also been created: 447 researchers and 193 engineers, technicians and administrators.

The new funds are not distributed equally among all research sectors supported by CNRS. The biggest fractional rise goes to an interdisciplinary programme of solar energy and primary materials (PIRSEM), which will get FF 10 million, over three times as much money as its predecessor PIRDES.

Besides that exceptional case, applied physics (physical sciences for the engineer) is most favoured: it receives a 40 per cent rise. Life science gets 38 per cent, earth science 36 per cent. Life science gets the biggest share of the new research posts (127) but then it also has the biggest share $(2,500)$ of the total research staff of CNRS. The budget increases will be used for four principal purposes. First, to re-equip laboratories to "bring their means back to an internationally competitive standard". General laboratory spending suffered a severe decline between 1972 and 1980, say CNRS staff. The previous science minister, Pierre Aigrain, won a substantial increase in the general science budget in 1981 ( 8 per

\section{Pressing problems for Payan}

THE major issue facing the CNRS director-general, Jean-Jacques Payan, and president, Claude Fréjacques, is the reorganization of CNRS - to which the new government and CNRS directorate are committed.

At present, CNRS is structured around a remarkable scientific parliament called the Comité National, which consists of about 1,000 people, roughly two-thirds of them elected every four years from CNRS laboratories and groups and onethird nominated by the government from among scientists, industry and the administration. Researchers, engineers, technicians and administrators are all represented. The Comite is divided into 41 sections according to discipline. In spring these sections advise on individual careers and promotions, and in autumn they consider the prospects of groups and laboratories.

This advice passes to the eight scientific directors of CNRS, who are usually career scientists who spend a period of 4-8 years on part-time leave from their posts to direct a sector of CNRS activity; and then to the "double head" of CNRS, the director-general and president. Ultimately, major decisions are taken by the governing body of CNRS, the government-nominated Conseil of which Fréjacques is president.

To those interested in increasing "democracy" in French science - which means effectively reducing the power and influence of the scientific directors of CNRS and, at the local level, of laboratory directors - the Comite National plays a central role. The scientific trade unions would like to increase their control and influence over

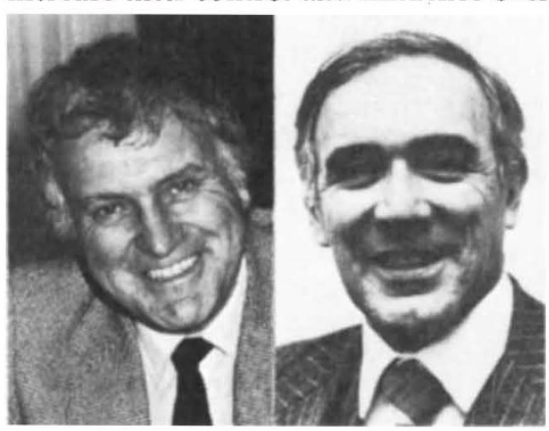

Payan (left) and Fréjacques face the unions

the parliament. Commensurately, it is felt that the powers of the parliament itself should be increased.

A struggle is taking place between these unions and the directorship of CNRS. The unions demand that nobody be elected to the Comite National unless he or she is accredited by a union - which represent mostly technicians, engineers and some younger researchers. Payan has sent a letter to laboratory directors to warn them of the threat and ask for their advice. One senior scientist cabled Payan to say he would resign all his CNRS functions instantly if the unions were granted such power - and his reaction may not be untypical.

Professor Payan himself is shocked by the union militancy. He said recently that the thorough-going dialogue now under way in CNRS touched all levels, and that CNRS old hands had not experienced such a thing for a long time [since 1968, perhaps]. But, said Payan, whereas the union position against the previous rightwing government had understandably been "the most extreme possible", now was the time for a more comprising attitude. Was the socialist government not, after all, on the same side?

A second important - but less pressing - issue facing Payan concerns the relationship between CNRS and the universities. Under the previous government, CNRS was under the authority of the Ministry of the Universities, but now it is controlled by the Ministry of Research and Technology. Since CNRS already creams off some of the best scientists from education, this shift has led the universities to fear a deepening of the class divisions between university and CNRS laboratories.

This fear is further increased by plans to give CNRS a role in the education of researchers. But, says Payan, a break between the universities and CNRS would be a bad thing. CNRS will cooperate with the universities, he says - but, on the other hand, the universities have a long way to go . . . 
cent in real terms, he claims), and this year that trend is accelerated to 25 per cent in real terms.

Second, the aim is to bring to fruition certain plans for large machines - the heavy ion nuclear accelerator (GANIL) and a French dedicated $800 \mathrm{MeV}$ synchrotron radiation source, Super-ACO, at Orsay (in collaboration with the Commissariat a l'Energie Atomique, the Ministry of Universities, and the Universite Paris-Sud). Increased support will be given for the reactor Orphée and the trinational high flux neutron beam reactor at the Institut Laue Langevin in Grenoble.

Third, new themes of CNRS support are to be established, particularly through the special programmes called Actions Thematiques Programmées (ATP) under which CNRS laboratories and groups compete for extra money available for work directed to particular objectives which are becoming increasingly technological. This year ATP cash has crept up to nearly 10 per cent of the research money otherwise available to CNRS laboratories.

Finally, FF 8 million have been set aside for a programme of so-called "young groups", which is designed to give younger researchers a chance to create their own groups earlier than would otherwise be the case. The programme also gives CNRS the chance to go head-hunting in some of the smaller universities for new talent. The name "young groups" may be a bit misleading, however: the eight "young" group leaders recently selected by the life sciences sector of CNRS are all about 40 years old. "We hope we can bring the age down somewhat next year" said a CNRS spokesman.

\section{Medicine hot, agriculture cool}

CONTRASTED with the scale of the CNRS, the institutions which support health, medical and agricultural research may seem small, but they have a significant impact on research. INSERM, the Institut National de la Sante et de la Recherche Medicale, supports 1,500 researchers (compared with 2,500 in the life sciences sector of CNRS alone). Even so, this is over a third of French biologists, and the means at INSERM's disposal are not negligible: over FF 1,000 million this year. Since the CNRS life science budget is just under FF 1,000 million for nearly twice as many researchers, INSERM scientists can count themselves rich.

INRA, the Institut National de la Recherche Agronomique, is also substantial - although until recently it had appeared to have been neglected by the new government. INRA has 200 researchers and a 1982 budget of FF 1,400 million. INRA is unusual in being highly decentralized, as befits an agricultural agency, with laboratories all over France and also in Corsica and Guadaloupe.

INRA politics, for the moment, are relatively quiet: INRA's director-general, Jacques Poly, has not yet felt obliged to resign over some difficulty or other with the new minister of science - unlike his former colleagues at CNRS and INSERM, who did just that. But perhaps that is because the ministry has hitherto paid little attention to agriculture. Earlier this month, however, the establishment was announced of a new department at the ministry of research and technology, to be concerned with agriculture and food.

Chevenement appears to have noticed that the agroindustry employs 3.5 million workers, and that its activities concern every consumer in the country.

The new department will assess the present state of research and development in this area in France; define priority research areas; stimulate relevant research in small industries and businesses; extend the links between INRA and industry; establish the needs for training and recruitment; and take account of the needs of developing countries.

What Professor Poly makes of this has yet to be seen, but meanwhile the new director-general of INSERM, Professor

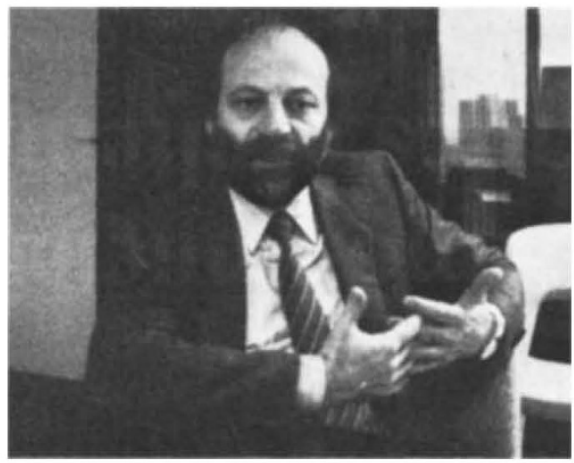

Lazar - back to the watering can?

Philippe Lazar, is settling in after his predecessor's resignation. That gentleman, Professor Philippe Laudat, was very oblique about his reasons for resigning, but the speculation is that he feared that his efforts to concentrate INSERM funds on the best groups, so avoiding what he described as "an even sprinkling" of money regardless of quality, would be reversed by the new government. As what Laudat identified as "best" often meant groups working in molecular biology, INSERM researchers in that area are worried.

For Professor Lazar, if anybody, would be the one to apply the politics of Chevènement to INSERM: he was rapporteur for the National Colloquium of Science and Technology in January. So what does he plan to do?

Laudat certainly had trouble with the scientific trade unions, with his determination, as he put it, to open up INSERM research; and Lazar will clearly be more sympathetic to union views. Lazar sees no reason to be so selective with basic research money as was Laudat, because research funds for all basic science are guaranteed to rise 13 per cent in real terms (according to Chevènement's forthcoming law).

"We should try to mobilize almost all research units" says Lazar, "and be a little more confident in the ability of all groups"'. It is possible to be too elitist, he says. How is one to detect which research unit is going to be successful, as opposed to those already at the top?

Lazar intends to apply a policy of $a$ posteriori, rather than a priori assessment: each of the INSERM units will be expected to present a programme every two or three years in which it expresses its needs; INSERM will then respond. This will save laboratory directors time in their constant efforts to raise money. Each unit will be assessed at this one time by INSERM's eight specialized committees and scientific council, which will give advice on the closing of certain units and the opening of others. But the specialized committees should "follow each laboratory more closely and interfere more".

It should be easier than at present to change the directors of laboratories, says Lazar. As thing stand, a director is appointed for six years - after which he or she is assessed and, almost without fail, reappointed. "The general rule should be that a director should change", says Lazar.

Lazar also feels that the links between the INSERM administration and its scientists are too weak, and he would like to make use of the 225 committee members more than the present twice a year; and he wants to try to improve INSERM's links with the outside world, including CNRS, the Institut Pasteur, the universities, and institutions beyond France.

\section{CNRS and INSERM}

Lazar would like particularly to rationalize the overlapping relationship with CNRS, a desire shared by CNRS director of life sciences, Professor Roger Monnier. Sometimes both INSERM and CNRS support the same laboratory in different ways, and neither knows what the other pays. Lazar favours joint committees set up between CNRS and INSERM.

Of molecular biologists relying on INSERM grants, Lazar says "they may be afraid but I am not'. Molecular biology will receive "at least 13 per cent" in real budget rises in coming years - as a basic science - and in so far as the work is linked to biotechnology, nearer 30 per cent. For Lazar will countenance certain programme mobilisateurs which will receive more than the average attention. Biotechnology will be one; also the social sciences of health care. Clinical research, generally thought to be weak in France, will also receive special attention, by "opening it up to other research". Lazar intends to hold a meeting to illuminate that issue. 


\section{Biotechnology - gearing up}

BIOTECHNOLOGY - including the most basic molecular biology - is to be one of the principal axes of M. Chevenement's French technological revolution. Moreover it is the first of his ministry's programmes to get off the ground, because its main points are identical to those followed by the previous government. This is not least because the biotechnology adviser to the previous government now spearheads Chevenement's biotechnology department at the ministry. $\mathrm{He}$ is Professor Pierre Douzou, a well-known microbiologist at the University of Paris. The only obvious change from the earlier policy seems to be the fivefold budget increase.

The main weaknesses in French biotechnology have been identified as a woeful lack of microbiologists, a poor system for training genetic engineers, too little work on plant cell biology and weak links between the worlds of research and industry. The genetics of nitrogen fixation is also thought to be poorly represented in France; and lastly, the French pharmaceutical industry is particularly weak in the antibiotic market, and so has little experience in the sophisticated fermentation technologies that antibiotic production requires. On the other hand,
France can boast some world-class groups in molecular biology, particularly at the Institut Pasteur and the University of Strasbourg. The lack of microbiologists is perhaps surprising in the country of Louis Pasteur, but just as in other countries, French biologists have followed the trend towards concentrating on "laboratory" species such as Escherichia coli. To correct the trend, CNRS is planning to set up new groups or laboratories working with species such as Pseudomonas or Actinomyces, and, they say, they are ready to import the right group leaders from abroad. French universities are also preparing to establish professorships in microbiology. Also, plans are almost complete at CNRS to establish a new laboratory of plant genetics in Strasbourg, at a cost of around FF40-50 million, which will employ 100 scientists.

At the Institut Pasteur in Paris construction is going ahead on a new building devoted to biotechnology, to open in 1984-85, according to a decision taken by the previous government. Among other things the building will provide facilities for 5-10 litre fermentation trials and will have a laboratory for the development of hybridomas.

\section{DESOXYRIBONUCLELQUE?}

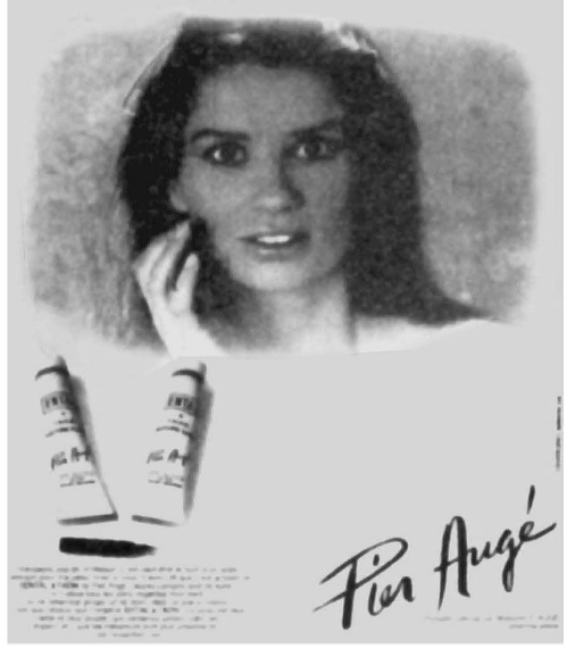

Science and the scientific are chic right now in France: witness this advertisement for DNA cream from a French magazine.

At present the strong poles of CNRS biology with an impact on biotechnology are at Strasbourg (basic molecular biology and plant science), the Institut Pasteur (all fields), Toulouse (selected by Aigrain to be a special centre for biotechnology), Marseilles (laboratories of immunology

The latest effort to be announced is a massive trial of a new vaccine against hepatitis B, produced by Institut Pasteur Production, on 200,000 Senegalese children, in conjunction with the Institut Pasteur (Dakar) which is one of the 26 institutions around the world linked to the Pasteur (Paris). Nine out of ten adult Senegalese are infected with the virus, it is estimated. If the trial is successful, there is a big world market for the vaccine.

The Pasteur is also gearing up to train the bioengineers that France will need. Special training will be given to engineers emerging from certain grandes écoles. Links have been established so far with Polytechnique, Centrale, Mines, and Ecole Nationale Superieure de Physique et Chimie de Paris. pathogens (its traditional interest) towards microorganisms of potential economic importance. Now he has become science adviser to the Prime Minister, Pierre Mauroy, where he has considerable influence. Moreover, the National Colloquium on Science and Technology, the great conference of scientists and public that has been one of Chevenement's most imaginative achievements, was Gros's idea. Gros organized and chaired the colloquium, so endearing himself to the new minister of science as well as the Prime Minister.

On the practical side, the Pasteur is now seen in government circles as an excellent model of the combination of fundamental research with industrial and medical development, a kind of mix of priorities which can be traced directly back to the inspiration of Pasteur. The
Pasteur has a hospital. It has research which it tries to exploit its research.

There is Institut Pasteur Production, which has a first call on potentially discoveries at the Pasteur; Groupement Genie Genetique (G3), which seeks directly to develop profitable ideas, which it would then license to industry; and a highly differentiated and active system for linking Pasteur staff with industry, making a profit for the Pasteur and aiding the biotechnology industry at the same time.

The original Institut Pasteur building of 1888. Pasteur's tomb (see cover) is on the site.

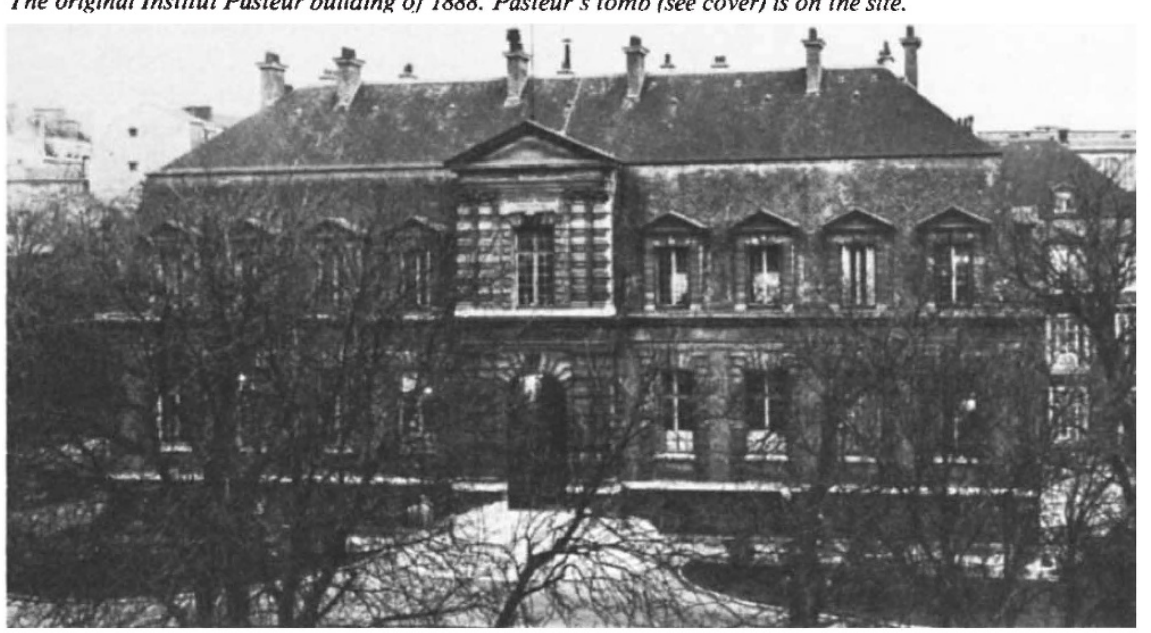


and bacterial chemistry), Compiegne (enzymology and enzyme fixation) and to a lesser extent, Lyons and Montpellier.

Douzou outlines the principal objectives of the ministry as first, to improve training and education in the field; second, to transfer information more efficiently from the laboratories to industry; and third to establish "a multitude of sites" in France as small technology centres, which would embody perhaps four or five researchers, several engineers, and technicians, each working on some pilot scheme. These technology centres should be encouraged in industry as well as in the public sector such as CNRS and INSERM, says Douzou.

In that public sector, Chevènement has said that such laboratories would be judged by the patents achieved, by licences sold to industry and by their general impact on the industrial sector rather than by their scientific productivity per se.

However, development work in biotechnology can be very expensive, and France is certainly willing to consider international agreements and programmes at that level. They should be bi- or trilateral and specific, however, rather than conducted through an intermediary like the European Commission in Brussels.

\section{Industry cloning}

FRENCH industry boasts a handful of main actors in genetic engineering. They are Transgène, a venture company with a small amount of government support based in Strasbourg; Genetica, a genetic engineering wing of the chemicals giant, Rhone-Poulenc; G3, a group based at the Institut Pasteur in Paris and supported by government money through CNRS, INSERM and INRA and ( 51 per cent) by the Pasteur itself; and the nationized oil company Elf Aquitaine. Elf is to set up a FF100 million biotechnology laboratory in Toulouse, and through its pharmaceutical subsidiary Sanofi it has a 51 per cent share in Institut Pasteur Production, the company with first claim to the development rights of Pasteur Foundation discoveries.

None of these companies except Institut Pasteur Production (which is a an older company with a strong interest in vaccine production) yet has a marketed product, and all are keeping their plans fairly close to their chests. But Transgène, at least, is known to have commissioned reports on the microbial extraction of minerals from sea water and to be considering a special effort on plant cells - stimulated by CNRS plans to make Strasbourg a focus of plant genetics. Transgène's director, Jean-Pierre le Coq, is also looking closely at what the new biology can do in traditional biological industries such as food processing - where, he says, the field is huge and the competition less.

\section{Telecommunications - late start}

FIVE years ago, the French ministry of telecommunications, PTT, launched an ambitious plan to improve the services offered by the public telephone network. Since then, massive investment has increased the number of telephone lines from 7 million to 16 million. When he presented his budget to the assembly earlier this year, Louis Mexandeau, the new PTT minister, indicated that he wishes to continue the modernization albeit at a slightly slower rate. He is looking for a further FF 25,000 million a year for the next five years to give a telephone to everyone who wants one by 1985 .

As PTT admits, the success of the modernization so far is partly due to the initial small size and poor state of the telephone network. France has been able to opt for the latest technology and avoid the problems inherent in modernizing an outof-date, yet extensive, system. Hence, for example, France has been able to move over to fully electronic exchanges move rapidly than some of its European neighbours. The plan now is to digitize the network fully by 1990 .

To achieve its goals, however, PTT has had to lean heavily on industry. Although the result has been to increase the international competitiveness of the French telecommunications industry, there have been problems along the way. Pierre Aigrain, former science minister who has now returned to his old haunt Thomson CSF as research director, mentions the difficulties caused three years ago when PTT changed suddenly from installing partially to fully electronic exchanges.

The switch meant that Thomson had to reduce its workforce, a task it has still not managed to complete. Thomson was also at a disadvantage because, unlike its competitor, CIT-Alcatel, it did not receive state help to develop electronic exchanges. PTT supported development in its own research centre, the Centre National d'Etudes des Telecommunications (CNET), and then licensed the product for manufacture by CIT. The CIT product works well, but Thomson is still having software problems.

(The PTT supports most of its research on electronics at the CNET laboratories in Grenoble, which, like the laboratories of CNRS, have been asked to step up the number of researchers employed by 4.5 per cent a year. The ministry of research and the PTT now want the Grenoble laboratories to develop into a major centre that will drive not only telecommunications but also the broader electronics industry.)

\section{Switching to optics}

The French have also been fortunate in their choice of technology. By choosing a time division switching electronic exchange, they have suffered fewer technical problems than say Britain with its choice of System X. But installing electronic exchanges is just the first step in PTT's vision of transforming the network into a modern system for digital rather than analogue transmission.

Like its European neighbours, it is nibbling vigorously at the bait of optical fibres. Thus a $12 \mathrm{~km}$ optical link has been installed between two telephone exchanges in Paris and two more links are planned.

Optical fibres are still too expensive for widespread introduction, largely because the signal has to be boosted at regular intervals of about 30 kilometres. The PTT will be waiting until the price comes down to about FF1 per kilometre. But SaintGobain and Thomson CSF seem confident that the market will expand soon. Recently, they formed a joint company, Fibres Optiques Industries, with Corning Glass, to manufacture $10,000 \mathrm{~km}$ of optical fibres a year, half planned for export.

Optical fibres are also being connected to 2,000 households in Biarritz in the south of France for an experiment, beginning in 1983, that will give each household access to new telecommunications services such as videophone, videotex and cable television, via a telephone linked to an ordinary television screen. A further experiment to bring cable television via optical fibres to the people of Lille is also planned. The aim is to test the usefulness of new technologies and the information they bring to individuals and businesses before launching into full-scale development.

Planners seem particularly keen to bring new telecommunications technology to the business community. In 1983, French companies will be able to make use of the services of a satellite more or less devoted to business communications when Telecom 1 , a satellite being built with PTT backing under the direction of the French space agency, CNES, is launched. In addition to providing business links, Telecom 1 will free France from the expense of leasing channels on Intelsat satellites for telecommunications links with its overseas territories.

The Mitterrand government clearly shares the view of its predecessors that modernization of the network is essential. But where the old and the new policies may part company is in a strategy for widespread introduction of télématique - the uniquely French word for the information systems created by linking computers via telephone lines - into homes. The new government is sceptical of the economics of the Giscardian plan to give every home a télématique terminal. And Jacques Dondoux, the new director of telecommunications, has made a concession to public anxieties about the social impact of télématique by agreeing to set up a users' group to discuss the issues.

The previous plan to install and experimental electronic telephone directory into every home in Ille et Vilaine in Brittany has 
thus been modified to give householders the right to refusal. Householders in Velizy, a small town near Paris, are also to be allowed to choose whether to participate in an experiment to monitor the use of Teletel, the French public viewdata system. The results of both these experiments, which began last year, will be fed into a national debate on the new technology.

PTT plans to finance its future investment programme in much the same way as it has in the past - from earnings and money borrowed abroad. As the network grew, the proportion of investment raised from receipts grew from 43 per cent in 1977 to 74 per cent in 1980 . The hope is that three quarters will come from cash flow.

Thus the pressure on the public purse should continue to be minimal. But the Mitterrand government, in its eagerness to offer the benefits of new telecommunications technology to everyone that wants it, has already suggested that PTT offer special tariffs to certain groups, for example the elderly. If it sticks to its guns, then PTT will be looking for public money to make up the deficit. Judy Redfearn

\section{Microcomputers for all}

WHILE other countries agonize over the social impact of new information technologies, France is preparing to take the bull by the horns in the form of a new centre set up last October with an annual budget of FF 100 million. The Centre Mondial, as it is known, is the brainchild of Jean-Jacques Servan Schrieber, author of the book The World Challenge, who believes that microcomputers can wipe out social inequality by bringing information to all. Last week, the Centre Mondial held its first assembly.

Professor Nicholas Negroponte, professor of computer graphics at Massachusetts Institute of Technology is managing director. He will be supported by a board consisting of 12 French cabinet ministers and a group of French and foreign scientists. Around 50 researchers will be appointed this year and a further 50 by the end of 1983 .

The idea, however, is not simply to get computer scientists to design micro- computers. The public must also be involved in testing new and existing information technologies. Hence the centre will be establishing offices where passers-by can test out various wares. The ultimate aim is to feed public reaction into the design of a powerful microcomputer, costing no more than $£ 100$, for personal use.

In the meantime, the centre will study social questions such as the human-computer interface and the value of information technologies to members of different cultures. Two projects have begun. One, to bring microcomputers to a quarter of Marseilles in collaboration with the University of Aix at Luminy, will test the French response to the new technologies. But the other, to train young people from Senegal in the use of microcomputers, will be used to assess the usefulness of the new technologies to those living in developing countries.

Judy Redfearn

\section{National trend in space}

THE enthusiasm of the Mitterrand government for science and technology has not been lost on the Centre National d'Etudes Spatiales (CNES), the French national space agency. CNES has been promised 18.7 per cent more money, in real terms, in 1982 than in 1981. The lion's share of the FF 3,000 million budget for this year, which makes CNES the largest national space agency in Europe, comes from the research ministry. But other government ministries which must contribute towards development of services they wish to use have also stepped up their payments. These include the ministry of defence, which wishes to launch satellites on Ariane, and PTT (the telecommunications ministry) which is contributing towards the cost of Telecom 1, a national telecommunications satellite.

For the time being at least, the new government seems keen to support the space policy of the old. Thus, last October it formally approved CNES's involvement in four new projects of the European Space Agency (ESA) and a second national remote sensing satellite, Spot 2 . CNES will have no difficulty spending this year's extra money according to Professor Hubert Curien, the centre's president, largely because Spot 1, the first national remote sensing satellite, is now entering the most costly phase of its development. But if the budget continues to increase over the next five years, as promised, how will it be spent? CNES hopes to persuade its own government and those of its partners in ESA to embark on projects that rely less than in the past on the good will of the United States and the Soviet Union for their success.
Since CNES was created 20 years ago this month, it has followed a policy of multilateral and bilateral cooperation that has benefited both national space industries and the space science community. Hence, membership of ESA has given French engineers the opportunity to participate in the development of their brainchild, Ariane, a project that would have been too costly for national development. And the policy of bilateral cooperation with the Soviet Union as well as the United States and individual European countries has given the French space science community perhaps more opportunities than its counterparts in, say, Britain and Germany.

International collaboration, however, has not always run smoothly. CNES still remembers, for example, NASA's decision to withdraw from participation with ESA in the International Solar Polar Mission. Joint projects with the Soviet Union have caused similar frustrations. And the decision of the Soviet space agency to extend its next mission to Venus to include Hally's comet meant that CNES had to abandon plans to send a probe into the atmosphere of Venus.

CNES now wants to shake off the shackles of being the junior partner in collaborations with the two space powers, whilst retaining a strong commitment to Europe on the grounds of necessity. It is following two paths towards its goal. The first involves persuading the French government to support an enlarged national space programme, especially in science. And the second involves persuading the members of ESA to develop an ambitious launcher as a successor to the current series of Arianes.

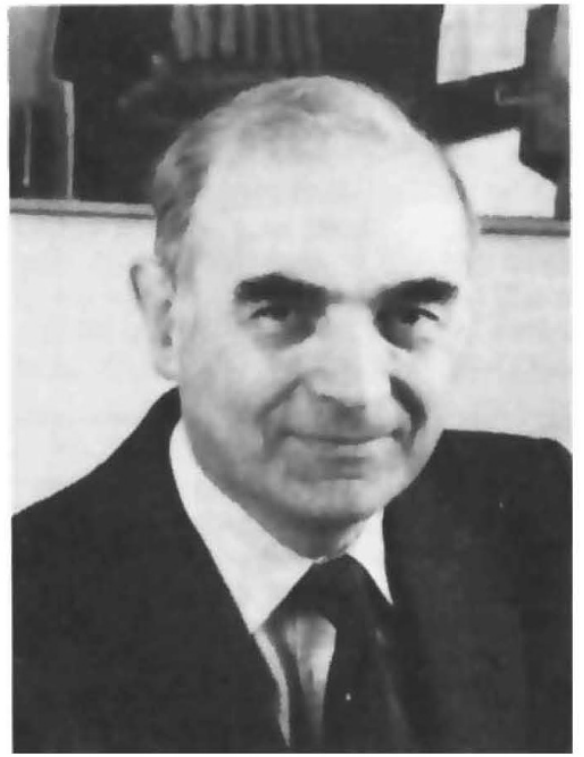

Hubert Curien - keen to promote ESA as senior partner in bilateral projects

The national space programme centres on the development of applications satellites, five of which will be launched in the next three or four years. These include a telecommunications satellite, Telecom 1, due for launch in July next year; a direct broadcasting satellite, TDF 1, identical to West Germany's "TV-sat"; and two Spot remote sensing satellites for launch in 1984 and 1985. But when these projects come to an end, CNES may well decide that most future research and development in applications, especially telecommunications, should be hived off to national industry which has already developed more expertise in space technology than many of its European counterparts. 


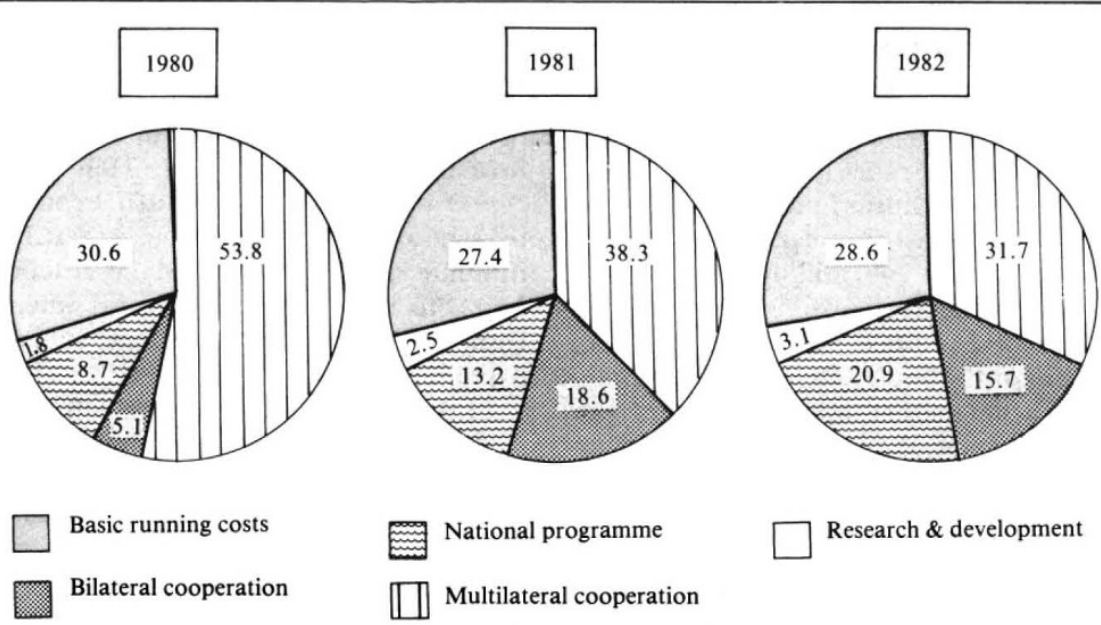

Allocation of the CNES budget 1980-82. Basic running costs includes the cost of ground facilities such as the technical centre in Toulouse. The amount spent on multilateral cooperation has decreased as ESA's programme to build Ariane has reached the end of the first development phase. The increase in the proportion spent on bilateral cooperation in 1981 was due to the start of the Venus-Halley mission with the Soviet Union and the Franco-German collaboration on direct broadcasting satellites.

The field could then be open for the first national scientific satellites since 1975 . The French space science community, enthused by the possibilities, thrashed out about ten proposals at a meeting last year for wider discussion at the national colloquium on science and technology held in Paris last January.

CNES is studying the feasibility of all the proposals, some of which will eventually be put to ESA. But two, a gamma-ray observatory, Sigma, and a wave altimetry experiment, Poseidon, have been singled out for national development. The reasons for choosing them were their scientific merit and the urgency with which they would need to be developed. The plan is to launch Sigma at the end of 1985 on the first qualification flight of Ariane IV, the latest

\section{Da ili nyet}

THE programme to put a French astronaut in space aboard Soyuz-Salyut later this year contributed to CNES's mistrust of bilateral deals when the Soviet space agency refused to release details of the spacecraft for reasons of military secrecy. French engineers then had no option but to guess the specifications for the instruments they are putting on board. In the event, the Soviet space agency allowed French technicians to travel to Moscow for consultation provided that they did not enter the buildings where the spacecraft were being built. But in general, when French engineers ask whether their guesses are correct, the Soviets simply reply "yes" or "no". The result, according to Professor Curien, is "trial and error with rapid convergence". Added to these technical problems is the growing row among French space scientists over the political wisdom of Soviet collaboration. Many are now objecting because of events in Poland and the human rights issue.

Judy Redfearn version of Ariane to be approved, and to carry the Poseidon experiment on board Spot 2.

CNES now has the task of persuading the French government to find the money for these projects, which could entail almost doubling the space science budget. Financial pressure could be eased, however, if other countries could be persuaded to participate as junior partners. Discussion over collaboration on Sigma has already begun with scientific groups in Italy and Britain.

Thus, with national scientific projects, CNES hopes to regain the power of decision it believes it has lost in many of its international undertakings. Professor Curien would like ESA to follow suit. France had supported moves by Germany at the end of last year to increase ESA's science budget by 20 per cent after 1983 . Other members states vetoed the proposition but CNES now hopes that if some of its scientific proposals cannot be afforded within ESA's mandatory science programme, then sufficient member states can be persuaded to participate on a voluntary basis.

Professor Curien believes that ESA too could gain greater control over joint projects with non-European countries if it initiated attractive projects in which, say, US scientists could be invited to participate. His proposal, however, has met with resistance from some members of ESA who fear that US participation could swamp what should still be essentially European projects. The outcome may depend on the findings of a committee of the European Science Foundation.

The strongest evidence of the importance that CNES now attaches to national and European independence in space, however, is to be found in its belief that Europe must build a new generation of launchers that will rival the descendants of the US space shuttle in the 1990s and beyond. At a meeting organized by CNES earlier this year, Yves Sillard, then director-general, urged representatives of the European space industries to come up with proposals within the next two years. The French idea is to develop an advanced launcher consisting of the first stage of Ariane IV with a powerful cryogenic motor for the second stage. A third stage could be added later. CNES engineers plan to put a proposal along these lines to ESA by early 1984 with the aim of reaching a decision in sufficient time for an operational launcher by 1994 .

The French philosophy is to design a flexible system that could launch the future generation of applications and scientific satellites and give Europe independence in new space applications such as material processing. The dilemma is knowing whether Europe will need men in space or whether it should design fully automated systems. CNES engineers are trying to avoid the problem by designing a partly recoverable, automatic system, initially compatible with Ariane IV, that could be converted to manned spaceflight, using the more advanced launcher, when and if the need arises.

Two separate but related projects are under study. The first, Star, a geostationary satellite that would maintain permanent contact between satellites and a ground station by relaying signals between them, may be affordable nationally. The second, Solaris - consisting of one or two Star satellites, an automatic space station in low Earth orbit and an automatic recoverable servicing vehicle - would be costly enough to justify collaboration within ESA. The recoverable vehicle would be of sufficient power to ferry, for example, materials for space processing between earth and the space station. It would also be capable of carrying out routine maintenance and repairs on the space station. Fitted with a suitable boost motor, it could be sent on servicing missions to satellites in geostationary orbit.

The development of both Star and Solaris demand research on space robotics and advanced control systems which CNES and ESA are currently supporting, albeit on a small scale. Ideas for putting men in space centre on developing a suitable recoverable servicing vehicle and space station for the Solaris system and a more powerful launcher. CNES is supporting feasibility studies of a small manned vehicle, Hermes, and a cryogenic motor with up to 100 tonnes of thrust for the second stage of the advanced launcher.

The French government, with its plans for dragging French science and technology to near the top of the international league and with its penchant for national independence through international collaboration, seems set to go ahead with these plans. But the success of CNES's proposals will depend critically on whether other governments, which may prefer to leave the expense of advanced launch systems to NASA, can be persuaded to play ball.

Judy Redfearn 


\section{Taking a nuclear power lead}

"ONE reactor, one producer, one seller"': that is the structure of the French nuclear industry, and according to one observer it is a prime example of how France has managed to mobilize its technical resources towards particular goals. Whether this technocratic centralism will survive a socialist government has yet to be seen, but the nationalization of large sectors of industry, and the grand "mobilization programmes" of the minister for research and technology smack not so much of a change as a clarification of previous government positions.

The reactor is the pressurized water reactor (PWR), built under licence from Westinghouse in the United States; the producer and seller the 5,000-strong company Framatome, now geared up in its pressure vessel and steam generators shops at Le Creusot and Chalon to produce six 1,300-MW reactors a year. Mitterrand did not nationalize Framatome. It was already in effective government control through its sole French customer, Electricité de France (EDF) and its principal collaborator in research, the Commissariat a l'Energie Atomique (CEA).

The main impact on the Framatome programme has been the reduction in the EDF order from a possible nine reactors over the next two years to six, which leaves Framatome with a large surplus capacity and a hunger for export orders. Framatome has sold one reactor a year for export over the past eight years: two to Belgium, both to come into operation this year, two to South Africa (to operate next year), two to Iran (although the orders were cancelled by Khomeni with the plants halfcompleted) and two to Korea. The sale to Korea was a considerable achievement because Korea's previous reactors had been constructed by US companies.

\section{Nucléaire, s'il vous plaît!}

A suigHr majority of the French people is in favour of nuclear power, a poll conducted just before the October 1981 energy debate indicated. Some 45 per cent are in favour, compared to $\mathbf{4 0}$ per cent against and 15 per cent who don't know, in a sample of over 2,000 people. On the extremes, 16 per cent were "definitely"' favourable, and 17 per cent "definitely" unfavourable.

One surprising result which might give the government pause, however, was that 64 per cent were in favour of a referendum on nuclear power - an election promise that was subsequently dropped. Another surprise: nuclear power is more supported on the political left than on the right. Compared with the average 45 per cent in favour, 51 per cent of those who voted communist and 52 per cent of those who voted socialist favour nuclear development.
Framatome has also put in tenders for two reactors for Taiwan and two for Mexico - and if it were not for the world recession would be confident of orders. The dollar rose by nearly 30 per cent against the franc during 1981 (from FF 4.5 to FF 5.8), giving Framatome a distinct price advantage - which is enhanced by the company's ability to spread its overheads over a large national programme. However, Mexico, at least, concerned about its economic situation, is beginning to have doubts about whether it needs the 20 reactors it was planning to build by the year 2000 , and the same fear appears to be gripping other developing
Coudray, is that while the Texas reactors are not likely to go critical before 1984 (three to four years late), the first Framatome $1,300-\mathrm{MW}$ reactor - at Paluel - should be connected to the grid early next year. Framatome will thus have taken less than six years to build it, whereas Westinghouse will have taken more than ten years for a similar reactor.

In part, this achievement can be put down to standardization. Framatome has not had to make substantial changes in design in mid-stream to meet changing safety regulations. Apart from the first five reactors, which were fairly variable Framatome was on its learning curve there have essentially been only three designs: a group of 16 reactors of $900 \mathrm{MW}$ which began construction in 1974-76; a

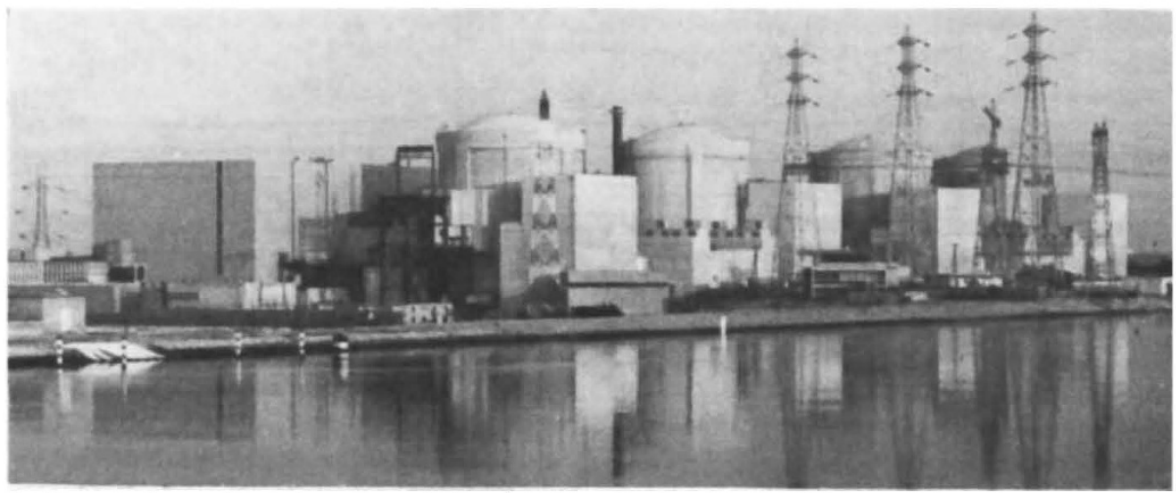

Pride and glory reflected - four of France's "production line" PWRs, at Tricastin

states interested in nuclear power. So Framatome may be forced to look to the home market.

In France, Framatome is now builaing 26 reactors witn a tutal power of $28.6 \mathrm{GW}$ electric, 16 at a nominal $1,300 \mathrm{MW}$ and 10 at $900 \mathrm{MW}$. Another thirty units, accounting for $21.8 \mathrm{GW}$, are already in operation. The smaller reactors are effectively the original Westinghouse design, as modified by Framatome; but the $1,300-\mathrm{MW}$ plants are almost completely French, and a new 1,400-MW design, called "N4" and now on offer to EDF, is totally so.

\section{Going it alone}

The Westinghouse licence expires this year and then Framatome will be officially on its own - apart from certain research agreements which will continue - but already the sluggishness of the US nuclear programme has given Framatome a commanding lead. According to Framatome's technical director, M. Michel Coudray, the company began work on the 1,300-MW design in 1975. By then Westinghouse had already sold two 1,300 -MW systems to a Texas utility, and Framatome believed that it would be able to benefit from Westinghouse experience before putting the final touches to its own 1,300-MW plants. But in the event, construction of the Texas reactors has ground almost to a halt. due to quality control problems on site and concern on the part of the Nuclear Regulatory Commission. The result, said second group of 12 begun in 1977-81; and the $1,300-\mathrm{MW}$ reactors, begun in 1977 in parallel with the second tranche of 900-MW systems. The result has been that Framatome has been able to place long orders for components, which gives a guarantee of supply, and streamlines production processes. (One danger, however, is that mistakes, once made, are propagated over many systems; see p.301.)

With this powerful prouuction system now established, Framatome would, of course, like a long list of orders; but even under the unbounded nuclear enthusiasm of the previous government, orders came only in occasional handfuls. Furthermore, EDF is now producing 40 per cent of its electricity from nuclear power, and while it aims for 60 per cent nuclear by 1985 (compare Britain's present meagre 11 per cent contribution), there is finally a limit to the proportion of an electric power network that can be driven by nuclear systems. The reason is that national power demand fluctuates by as much as 40 per cent during a working day, and nuclear power stations are not easy to turn on and off: they are said to provide " "base-load power". So already, EDF has insisted that Framatome consider the problems set by imposing a ten per cent peak to peak fluctuation on demand.

This so-called "daily load follow and frequency control mode" leads to a number of new technical problems, caused by the high frequency at which the control rods have to be driven in and out (up to 

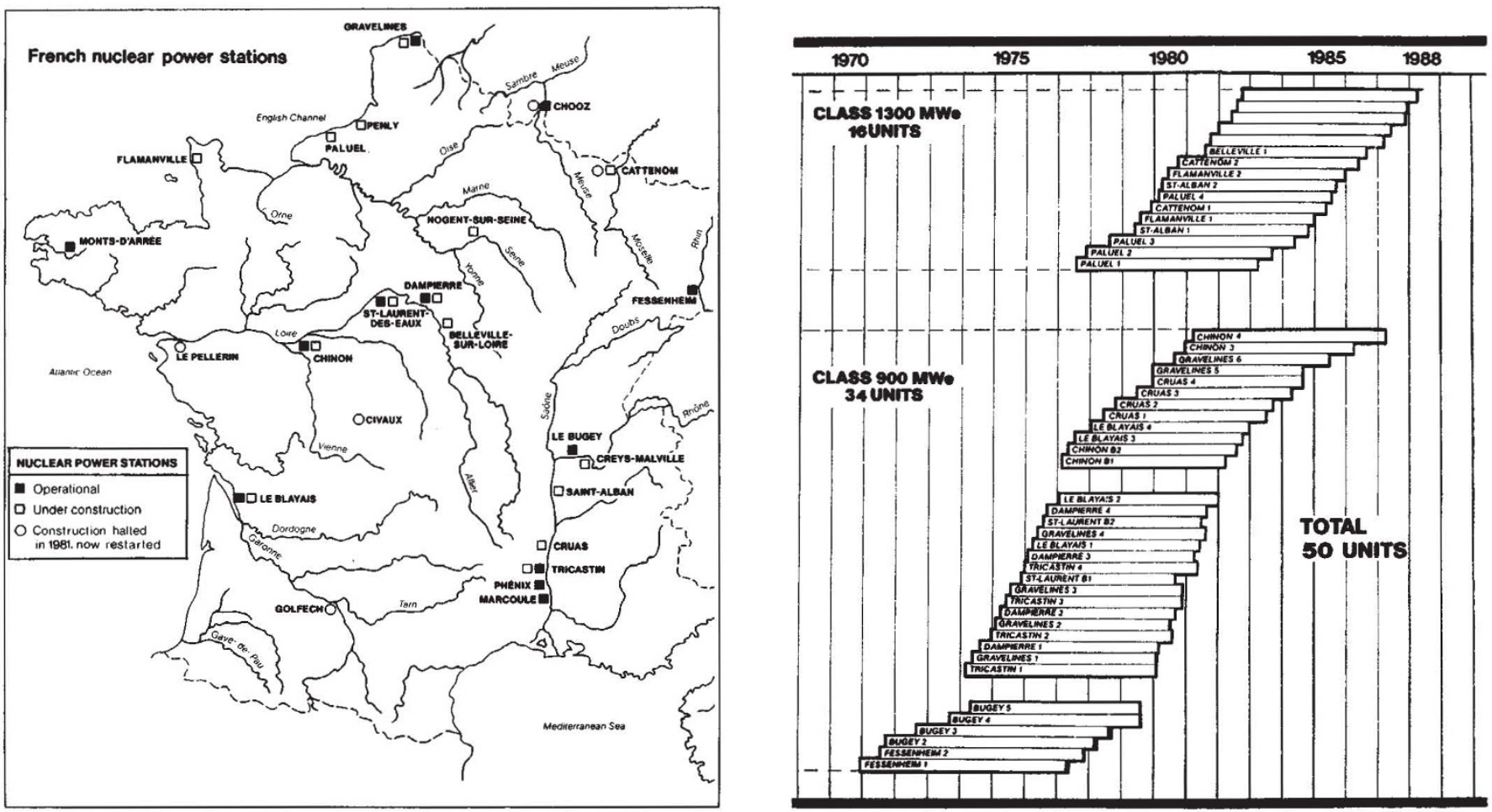

The map shows the sites of the French PWRs, filling many of the suitable sites on France's rivers. The figure on the right illustrates the pace of the PWR construction programme since the early 1970s. The boxes extend from the start of construction to connection to the grid.

1,000 times a day according to some estimates) and by the thermal stress on components as the core heats up and cools.

Nevertheless, Framatome has undertaken an extensive test programme at Cadarache, in conjunction with EDF and the CEA, to discover the behaviour of the reactors under such conditions, and the company believes it is now in a position to make the necessary design changes.

By 1990, French orders may be down to two reactors a year. Outside France, Framatome has sought to sell in many countries - including Britain, whose rejection three years ago of a possible arrangement with Framatome is still a bitter memory in the company. The UK Central Electricity Generating Board was said to be quite enthusiastic about an agreement with France over PWR construction, but the Atomic Energy Authority (AEA) was cool. "Britain could have had an industrial agreement, or a research agreement or both but she decided to go with Big Brother [the United States]', said Coudray recently. "Once again Britain has preferred America to Europe" he said, reflecting a feeling in France that Britain is on all fronts a reluctant European partner.

In the United Kingdom, the chairman of

\section{My steam generator's better than yours}

A KEY problem affecting the running of pressurized water reactors is corrosion of the steam generators - the massive heat exchangers that transfer heat from the primary coolant to boiler water which, as steam, will then be used to drive turbines.

Any boiling kettle makes a lot of noise and bubbling vibration, and the same is true of steam generators. So the tubes which carry primary coolant through the steam generator must be clamped firmly to stop them vibrating and working loose. Tight clamping leads to corrosion at the clamps. Loose clamping, as originally adopted by Framatome, leads to tubes working loose. (Fessenheim 1, the first French PWR, suffers from this.)

So steam generator design is something of a black art, and the engineers at Framatome think they've mastered it and that Westinghouse has not. Britain, for its PWR design, has adopted the
Westinghouse "F-type" steam generator. Framatome analysed the basic design of the model $\mathrm{F}$ in 1977-8 and was not impressed. The F-type is still just a design - it has never operated anywhere - and the previous model on which it was based had major problems. Westinghouse has solved some of the problems, but nothing like all of them, according to Framatome engineers. "We believe in rugged systems" said one. "The Westinghouse model is more of a watchmaker's approach, with smaller tubing of which there is no experience."

Westinghouse, however, is unperturbed. The company believes Framatome is wrong on water chemistry, and that the French steam generators will corrode within four years. However, $\mathrm{EDF}$, the operator, is proud of the chemical control procedures. "We are keeping our fingers crossed" say Framatome's engineers. the UKAEA, Dr Walter Marshall, sees things slightly differently. At the time of the French approach Framatome was still bound by the terms of the licence with Westinghouse, Marshall points out - so Britain would have had to "throw out Westinghouse", with whom negotiations were well advanced, without being able to sign up with Framatome until this year. Also Britain would have found it difficult to modify the French design to suit British conditions, for that would have been an implied criticism of French safety judgements, Marshall argues. Westinghouse itself, however, was more sanguine about design changes because it could always claim that in the United States its designs were bound by the rules imposed by the Nuclear Regulatory Commission, which might or might not be considered sensible. In France, by contrast, the closeknit character of the nuclear establishment implies that changes are a challenge to the whole system. The Framatome PWR is the world's safest, cheapest and best PWR: so why change it?

Another, purely commercial reason for rejection of the French deal was that there has been a recognition in Britain that Westinghouse, in the past at least, has been the world's most successful reactor vendor: and that on the other hand its credibility as a fuel supplier was severely damaged by President Carter's retrospective legislation on the supplies of enriched fuel. That leads to a natural partnership between Westinghouse and British Nuclear Fuels Limited (BNFL) whereas in a French deal BNFL would have been in competition with the French fuel company, Cogema.

Nevertheless, Britain's nuclear power capability would certainly have grown 
much faster with Framatome, and now France can gloat over the difficulties facing the British nuclear industry - particularly over the design and cost of safety systems. "We are very sorry for the British" said Coudray. "You can increase the cost of a plant by a factor of two if you are not careful with what you do about safety". According to M. Rémy Carle, a director at EDF, the cost of a Framatome 1,300 MW PWR station is now about FF 5,000 per kilowatt (that is, about $£ 600$ million in total) - a price that does not include decommissioning, and assumes a reactor on the coast, but includes all other costs. By contrast, at the recent announcement of the completion of the work of the British PWR task force, whose objective was essentially to reduce the cost of safety systems on the PWR, the figures being quoted were more like $£ 1,000$ million.

According to Coudray, the problem is that the British have adopted a four-loop, independently pumped emergency core cooling system (for use in the event of the most serious possible emergency, a "loss of coolant accident" or LOCA). Such a system is easier to explain, and "nicer

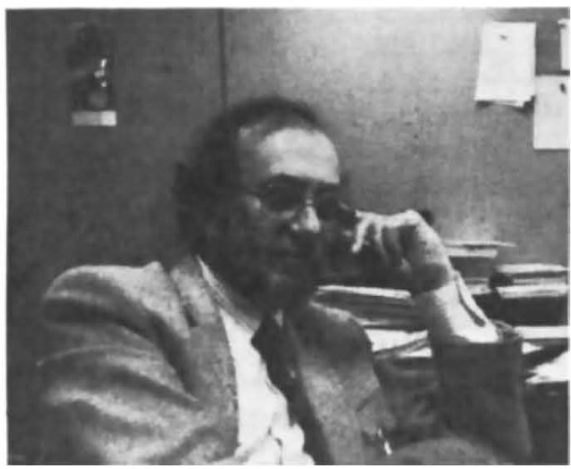

Coudray of Framatome - unlike the British, not troubled by a suspicious public

intellectually" that the French safety system, says Coudray. The British system takes five minutes to explain whereas the French takes 3-4 hours - but the French system will do everything the British one will do a much lower cost. Britain has probably adopted the "transparent" system for political reasons, thinks Coudray, to satisfy a suspicious public.

How then has France got so far ahead with its nuclear programme? The research programme undertaken by Framatome in the early 1970s, and which was in full swing by 1975 , was crucial to success. A licence brought information; but understanding requires research, said Coudray. Research enabled Framatome to move away from and improve on the Westinghouse design. The exact scale of the French research programme has not been revealed, but it matches anything that Westinghouse has done in the United States.

The company does its research under four framework agreements which allow very rapid changes of direction and commitments of money without the need for constant negotiation and renegotiation. Framatome has its own unique programme

\section{All they're cracked up to be?}

You couldn't really have a better recommendation. "Now's the time to buy from the French"' said Dr Walter Marshall, chairman of the United Kingdom Atomic Energy Authority, recently, when describing the French design for a pressurized water reactor (PWR). Dr Marshall heads the PWR task force which recently tidied up the design for a British PWR, built under licence from the American company Westinghouse. However, the recommendation is somewhat backhanded.

"The French have been caught with their pants down", said Marshall, referring to a series of cracks discovered in the reactor pressure vessel and steam generators of a number of plants three or four years ago. The result is that the manufacturers, Framatome, are now taking every possible precaution to avoid such potentially dangerous flaws, even though their own "pessimistic" calculations had shown the existing cracks to be unimportant.

Marshall says he has every confidence in Framatome's calculations and experiments, and believes that it has done a "very thorough job". French safety authorities will impose a requirement to inspect existing cracks every time a reactor is shut down for servicing (perhaps every 2-3 years), and Marshall - who made a deep study of the problems of cracking in reactor pressure vessels - believes this will be quite sufficient to prevent accidents.

This is despite the fact that some of the cracks, which appear in the black steel under the stainless steel cladding of the primary containment system, are difficult to observe. They are the ones in the shoulders of the inlet nozzles of the pressure vessel, where cool primary circuit water enters to extract heat from the core: it is simply physically difficult to reach them with the usual ultrasonic and eddy current detectors, unless the

at Creusot-Loire, mainly on materials; a "very privileged and active" programme with the CEA (which is, incidentally, a 30 per cent shareholder in Framatome); a quadripartite agreement, under which onethird of the work is done in the United States and two-thirds in France; and a tripartite agreement among the French partners. Corrosion problems in the primary circuit and steam generators, among the main causes of the low availability of the Westinghouse reactors, were studied under the quadripartite agreement; but surprisingly Westinghouse and Framatome then diverged over steam generator design (see page 300 ).

The principal reason Framatome has been so successful, though, lies in the extra- whole of the core is removed first. But Marshall believes it would be adequate to monitor frequently only the cracks in the hot outlet nozzles, which are accessible, as a kind of statistical sample of crack growth, while inspecting the inlet nozzles less frequently - say every ten years - a policy which Framatome and EDF will probably follow.

Around 25 of Framatome's earliest reactors are affected by the underclad cracking problem - an example of how design continuity can lead to problems if the design or manufacturing process has a hidden fault. But the cracks may prove to be a very minor hitch compared with another problem which became apparent only this January faults in the "broches".

These are spring clips which grip and support the fuel cans at the top of the core, and some three years ago in Japan it was discovered that they can be subject to embrittlement caused, perhaps, by neutron bombardment. Until January there had been no evidence of this in Framatome reactors, but then a loose part of a broche was found circulating in the primary coolant in one of the Gravelines reactors. Now the loading of the latest Framatome reactor, at Chinon, has been delayed according to some reports to test and inspect or even to change all the broches before the reactor is started.

Framatome staff do not understand yet what caused the Gravelines broche to break, and whether it was a unique or general fault. But if it was the latter, 37 reactors would be affected, so a crash programme on broche design and testing is now under way. The problem is compounded by the fact that the broches on working reactors will be highly irradiated and so very awkward to replace; but if faulty, they will have to be replaced, for broken broches could jam and interfere with the movement of control rods.

ordinarily tight organization of the nuclear industry in France - a legacy of the work of the previous industry minister, André Giraud. After the battle between CEA and EDF over whether the French gas-cooled or American pressurized water reactor should be chosen - a battle in which de Gaulle championed the CEA, which he had himself set up in 1945, and its gas-cooled system, and which was only won by EDF after de Gaulle resigned - Giraud picked up the pieces of the industry and dried the CEA's tears, giving it total control of the fuel cycle and the development of the fast breeder. He thus created the stable, threelegged organization - CEA, Framatome, EDF - which has put French nuclear power in a world-commanding position. $\square$ 


\section{Superphénix \\ great white hope}

THE world's first commercial-scale fastbreeder reactor, Superphénix, should be generating $1,300 \mathrm{MW}$ of electrical power for the French national grid by 1984. But is it, or will its successors be, economic? And will EDF order Superphénix II, which is already being designed?

Superphénix is in fact owned by an international consortium, NERSA, which is 51 per cent French with the rest largely divided between Germany and Italy (which has the larger share). NERSA is the customer of Novatome, a kind of fast-breeder companion to Framatome (which constructs the PWR). Framatome in fact now controls Novatome, which is also held 34 per cent by the CEA.

Superphenix is expensive: estimates vary, but the price is usually put at around twice that of the equivalent PWR. Of course, it is a prototype; it is alone on its site (PWRs are usually built in fours); and PWR construction is well-developed (Framatome is on the fortieth of its series). But there are some fundamental reasons why Superphénix should be more expensive: it has an extra cooling circuit the second sodium circuit; safety systems are more complex, having to deal with the possibility of sodium fires as well as almost instantaneous nuclear shutdown in the case of coolant loss; and the reactor vessel is stainless rather than ordinary black steel.

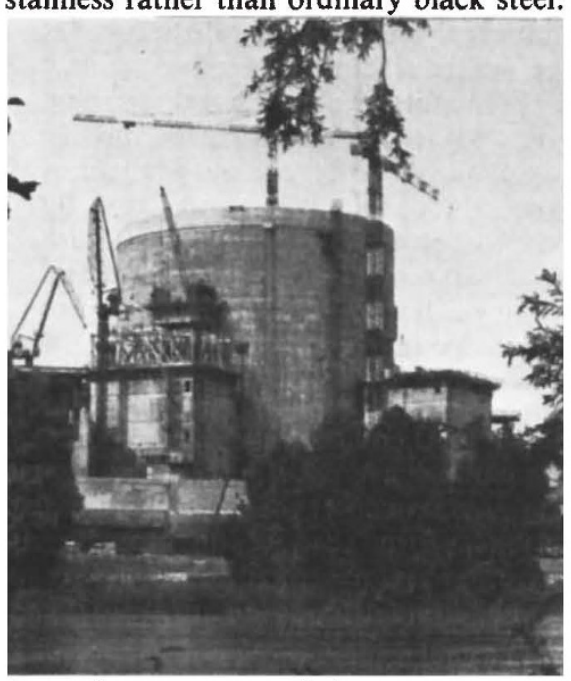

Superphénix nears completion

In the long run, the fuel cycle costs should be lower because the fast breeder can generate its own plutonium by neutron bombardment of waste uranium from enrichment plants and depleted gasgraphite fuel.

This would also give France a degree of security in uranium supply. French-controlled uranium production is expected to peak at around 4,500 tonnes a year by the mid-eighties, but the PWR programme is expected to need around 8,500 tonnes a year by 1990 and 12,300 tonnes a year by the year 2025 (according to CEA figures). So France is in danger of becoming almost as dependent on foreign uranium supplies as it is at present on foreign supplies of oil. The introduction of fast breeders, the CEA argues, could reduce this demand to as low as 8,000 tonnes a year in 2025 — provided a fast breeder programme were started soon.

There are two arguments for the fast breeder, says the CEA: that at a certain uranium price the fast breeder will become cheaper per kilowatt hour than a PWR, because of the former's breeding capacity; and that it represents an insurance against loss of uranium supplies. "And you expect to have to pay an insurance premium if you want insurance,"' says Michel Rapin, CEA director for nuclear applications.

The question of what balance should be struck between these two arguments is ultimately a matter for government and the electricity supplier, EDF, but neither shows any desire for haste although, says the CEA, France needs "a significant programme" of fast breeders by the end of the 1980 s to make any impact on French uranium needs by the second decade of the next century.

Moreover, the reprocessing and other pieces of fuel-cycle plant necessary for a fast breeder programme are uneconomic unless built very large. So the CEA is looking for two options: first, a French programme of seven or eight fast breeders, the first of which should be ordered in 1986-87 or, perhaps more practical, an international collaboration on fast breeder construction on about the same scale.

Of course it would appeal to France if the international reactor were close to Superphénix II, and the CEA has already

\section{Nuclear power}

WHEN François Mitterrand was elected president of France on 10 May 1981, the nuclear establishment was worried. His socialist party, a relatively new and unknown force in French politics, had committed itself to a fairly strong anti-nuclear policy. Paul Quilès, the architect of the socialists' plan, was effectively seeking a halt to the construction of new nuclear power plants. If this plan had been implemented, the monopoly electricity supplier (Electricité de France, EDF) would have had only $39 \mathrm{GW}$ of nuclear electricity available in 1990, compared with the 59 GW planned by the previous government, and EDF's supplier of nuclear steam supply systems - Framatome - would have found itself with (to say the least) an embarrassing overcapacity. With the export market also sluggish, this would probably have meant the collapse of the French nuclear industry.

However, six days after the presidential election, a strange thing happened. Giscard d'Estaing's centre-right government was in its last few days of limbo, before the elections to the National Assembly (parlia- been looking for partners. In Britain, UKAEA officials also believe in international collaboration on fast breeder programmes, and are contemplating agreements with either France or the United States. However, France was reported two years ago to be asking a price of $£ 20-25$ million for access to Superphénix technology, a price which Britain at the time rejected.

The reprocessing technology, whose efficiency in extracting plutonium is critical to fast breeder operation, is not seen to be much of a problem at the CEA. Already 15 tonnes of fast breeder fuel have been reprocessed through small fast breeder plants at La Hague (now closed) and Marcoule, and 380 of Superphénix's 400 or so fuel assemblies have been made of plutonium extracted through reprocessing. "We have closed the fuel cycle"' says Rapin.

Moreover the breeding efficiency was "sufficiently positive". In recent years CEA scientists - 1,000 of whom work on reprocessing technology - have reduced plutonium losses during reprocessing by a factor of five. "But that is not exactly the problem" says Rapin. To get a lot of plutonium bred by a fast breeder, a thick depleted uranium blanket is necessary. But the thicker the blanket, the less the concentration of plutonium produced in the outer layers of the blanket. And a low concentration of plutonium means a high reprocessing cost. So the best balance has to be struck between the reactor breeding ratio and these costs. Costs, yet again, come back to the centre of the fast breeder stage, and there are certainly some in France who look at Superphénix and think of another costly marvel - Concorde.

\section{how committed?}

ment) and the establishment of the new government. Usually, no major decisions or commitments are taken at such times. But Raymond Barre, Giscard's Prime Minister, unexpectedly announced that the reprocessing facility for spent nuclear fuel at Cap de la Hague, near Cherbourg, was to be massively extended - at an estimated cost of FF 20,000 million ( $£ 2,000$ million) - to cope with 1,600 tonnes of fuel a year. Some of this capacity was to honour contracts already signed with Belgium, Germany and Japan; but the rest implied a strong national nuclear programme. The decision could hardly have been taken without the tacit agreement of Mitterrand, who would have to carry the policy through. So what exactly was the new government's position on nuclear power?

Initially, it seemed as if the Quilès policy might be adhered to. One of the Mitterrand government's first acts was to "freeze" construction on five nuclear sites - Chooz, in the Ardennes near the Belgian border, Cattenom, Civaux, Golfech near the Pyrénées and Le Pellerin. Plans for a nuclear plant at Plogoff in Brittany were 
shelved, at least temporarily.

But then other notes were sounded. Jean-Pierre Chevènement, the minister of state for science and technology and a powerful figure in the new government, declared himself solidly behind the French nuclear programme, and all but described the small French environmental movement as "anti-scientific".

\section{Discarding the chaff}

Speaking cynically, it is as if Mitterrand had used the environmentalist tendency in his socialist party only so far as was necessary to help build the party and gain power. Now it was possible to let such chaff blow away. The environmentalists do feel themselves hard done by. Giscard had not even lent them an ear. Mitterrand had appeared to listen, and then ignored them. Recently there was a rocket attack on Superphénix, the world's first commercialscale fast breeder power station. Nobody has claimed responsibility, but there are fears at EDF that this means that an extreme section of the environmental movement has now gone underground.

Although the Mitterrand government can in no sense be called "green", it is showing itself to be sensitive to arguments for more democratic control of technical choice. Mitterrand is emerging as a social democrat, although he would not dare to use this label within his party.

In the energy sphere, the evidence for the socialist government's liberalism came first with an energy debate in the National Assembly last October. In contrast to the Quilès policy, the energy policy revealed by Prime Minister Pierre Mauroy and the junior minister for energy, Edmond Hervé, was very mild. It was forced through against the Quilès faction on a vote of confidence. Instead of $59 \mathrm{GW}$ nuclear in 1990 there would be $56 \mathrm{GW}$. Instead of nine new reactor starts in 1982-83, there would be six. The La Hague development would go ahead. The fast breeder was not debated. The frozen reactor construction sites would be reopened, if a local vote approved; if it did not, it would be up to the regional council (a higher elected authority) to decide; if the regional council did not approve, the matter would come before the National Assembly - a mechanism designed, it seemed, to get a "yes" vote at some level or other.

The environmentalist lobby looked on the black side - this was just the old centralist technocracy by another name. But there is another view, which as time passes comes more and more to the fore. The Mitterrand government is fiercely realistic - while at the same time wanting to make historic and lasting changes in the nature of French society. It is not going to compromise either on economic development or on a slow, emphatic shift of power away from the Paris-based élite, towards the regions, towards the small enterprises rather than the giant conglomerates.

Realism leads the government to under-

\section{Media plug in here}

JusT to the side of the Electricite de France (EDF) edifice in Paris is an unobtrusive set of doors. In the case of a major nuclear accident at one of the EDF power stations it is through this door that most of the world's (official) information about it will come.

For behind this door is a FF 4-million $(£ 400,000)$ communications suite, the brain-child and pride of EDF's chief public relations officer, Mme MarieClaude Vigna. Mme Vigna began to plan the suite after a French power black-out in 1979 had led to a great press of journalists in a tiny room in EDF headquarters, all attempting to use five telephones at once. If it was like that for a mere power breakdown, what about a "Three Mile Island", Mme Vigna reasoned?

The consequence is that EDF now has probably the most sophisticated "press office" in France. At street level, television vans can simply plug in to a series of channels giving television output from the suite above. Within the suite, sound-insulated rooms take tapes direct from the major wire services such as Energy minister Edmond Hervé confronts the press in EDF's media room

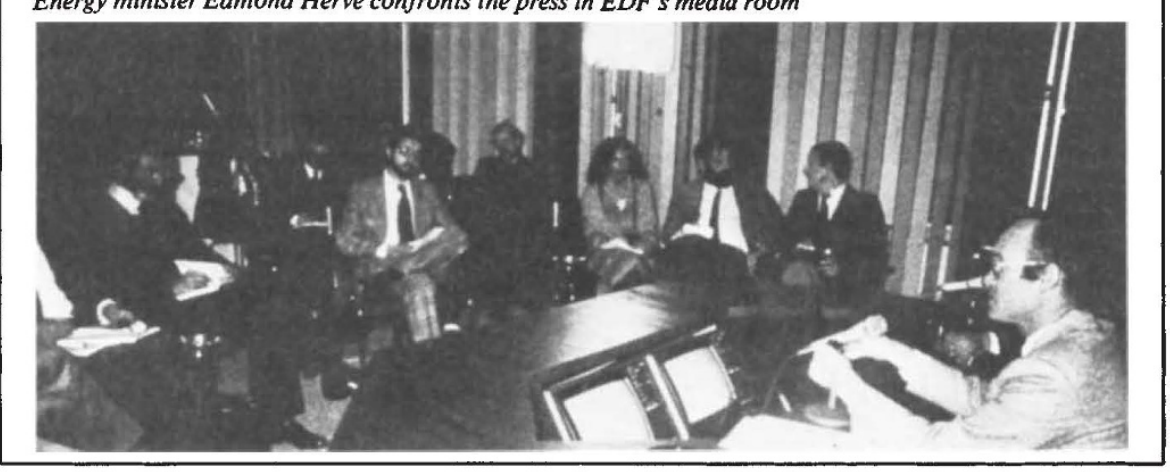

stand that a country 70 per cent dependent on foreign fuel, whose healthy non-oil trade balance is wrecked by the cost of oil imports ( 99 per cent of oil is imported), must attempt to internalize the costs of energy production. Nuclear electricity is part of the solution. The government is also realistic enough to know that the wholesale destruction of the nuclear industry would be immensely demoralizing to French people - who, while being as suspicious of nuclear power as the next nation, see its success as one of the great symbols of French strength. France has been overrun by a foreign power three times since the Revolution, and no Frenchman is going to let it happen again - either militarily or economically.

\section{Handling the public}

On the other side of the equation, the small group of men at the head of EDF, the CEA and Framatome, who effectively control the nuclear development of France, are gradually being forced to pay serious attention to the general concerns of the public and the particular demands of the regions
Agence France Presse and Reuters, so that journalists - and EDF staff - can monitor media output by the minute. There are of course more than five telephones; a television studio, executive briefing room; and literally every known form of video recording and playback equipment. And officials being interviewed can be relayed information over private monitor screens which are within their vision but not that of the journalists interviewing them (see photograph below).

Outside Paris, hundreds of EDF officials throughout France will be kept in touch by a private videotext signal, sent through the French ANTIOPE system.

A French prefect (regional head man) who was responsible for the region around the Dampierre nuclear power station recently sent out a notice to his constituents telling them what to do in case of a nuclear accident. Don't panic, he said. Keep your children indoors. Don't eat apples from the garden. And, mysteriously, don't telephone. Well, there'd be no need to with what EDF has in Paris, would there!

For example, when the government says it will "reinforce the independence" of the Conseil Supérieure de la Surété Nucléaire (the senior nuclear safety council) and "modify its composition", it means that it really will attempt to detach the safety council from its tutelage to the nuclear establishment. The proposal to create a "safety director" under the control of EDF may be looked at a little askance, as may guarantees of the independence of the Institut de Protection et de Surété Nucleaire, the technical safety assessment body which exists under and has constant exchange of staff with the Commissariat à l'Energie Atomique; but the establishment of local information commissions on each nuclear site could be taken more seriously.

These commissions are proving slow to set up (so far there is one at La Hague and another at Nogent-sur-Seine) but, according to commitments made by the government in the energy debate, they will be pluralist, "contradictoire"' (in other words allowing serious debate and close questioning), independent and permanent. 


\section{Hard bargaining at Golfech}

The apparently anodyne decision to subject the five frozen construction sites to a hierarchy of democratic assessments, from local to national level, until at some stage somebody said "yes", has also proved a thorn in the EDF flesh. The votes went in favour of continuing construction at Chooz, Cattenom and Civaux. But at Golfech, near the border with Spain, and Le Pellerin, there were marginal local votes against. So the question went to a higher level - the regional council. The Le Pellerin council voted for the reactor. But Golfech, while eventually agreeing, drew blood from EDF in the process.

The "blood" took the form of a contract with EDF - the first ever such binding arrangement between EDF and a region which guarantees the locality 40 per cent of the jobs that will eventually be created at

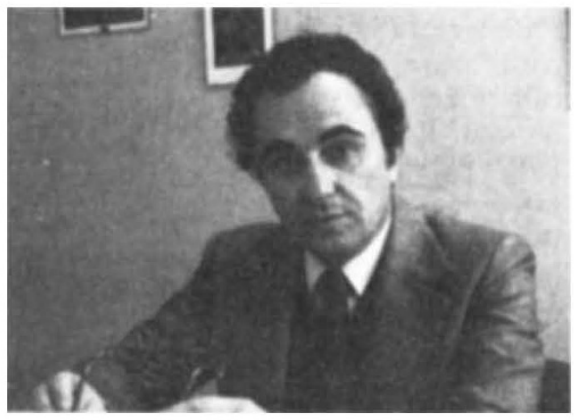

Michel Rapin of CEA says the nuclear programme is stronger under Mitterrand

the power station, a large fraction of the construction work and EDF support for amenity development. EDF is currently seeking sites for five reactors at 1,300 MV and one at $900 \mathrm{MW}$ - the programme agreed at the National Assembly for 1982-83 - and the Golfech deal may prove to be an awkward model. EDF, however, argues that it has always tried to place jobs and contracts around the region of a nuclear site. The real difficulty, says EDF, will be to find 40 per cent of its nuclear engineers in the Midi-Pyrénées.

The latest twist in the tail is literally there - at the tail end of the nuclear fuel cycle. Waste disposal has been neglected in France (although the Marcoule process for the vitrification of highly active waste has been adopted by Britain). Edmond Hervé, minister for energy, has asked the CEA to provide, within a few weeks, an outline plan for the management of nuclear wastes. No such plan exists at present, it seems. Within 18 months, two or three disposal sites must be selected, promising a new political problem for nuclear power.

Some in the nuclear establishment, however, are quite sanguine about the developments. Michel Rapin, director for nuclear applications at the commissariat, believes the new political approach will actually strengthen the nuclear programme, by providing a degree of democratic assessment. Once there has been a vote, who can disagree? All very well, while the votes are "yes". . .

\section{Trebling renewable energy by 1990}

ONE of the most surprising but rational moves made by the Mitterrand government in the energy field has been its appointment of Michel Rolant, a union activist in his late $40 \mathrm{~s}$, as the head of a completely revamped organization to promote renewable energies in France.

Rolant was an agricultural worker who took a strong interest in labour relations, and early on became general secretary of the federation of agricultural workers, a branch of the liberal union, CFDT. But his attention shifted to industry and employment, and he established a reputation, among the pro-nuclear lobby, of being totally anti-nuclear. Certainly, as CFDT's number two, Rolant moulded the union to form effectively the only organized opposition to the nuclear establishment - a position which it will retain despite Rolant's departure.

Electricité de France is turning a rather jaundiced eye on Rolant's appointment - the cosy club of grandes écoles men at the top of the ministries and the great industries is being jostled these days by one or two workers with some peculiar ideas - but for the government the move is really a master-stroke (and, by the way, one long advocated by CFDT). For, from the nuclear point of view, one of the principal irritants has been mollified: he to be determined. The CFDT recommends a balanced regional and central organization, with 22 regional branches each with perhaps 50-100 staff, and a 600-700 strong national body. (By comparison, COMES and AEE presently have about 500 staff mostly in Paris). The new body should also be capable of doing research on its own behalf, together with the major research organizations.

Moreover if capital loans could be arranged on the kind of terms on which they are offered to Third World nuclear purchasers - terms such as 8 per cent interest to begin five years after completion of a reactor as were offered to Korea, for example - then wonders could be worked, say the enthusiasts.

In fact COMES announced an objective at the end of last year: to treble the funds devoted to solar energy between 1981 and 1985. The most promising areas for development were the production of petrol and methane from biomass, particularly wood waste of which France has a particularly good supply. But Rolant will want to see all alternatives, including energy saving, in perspective, and perhaps COMES's priorities will not be his. The government is certainly committed in principle to a trebling of funds for renewable energy projects, although the allocation of the

\begin{tabular}{|c|c|c|c|c|c|}
\hline \multicolumn{6}{|c|}{ Consumption of primary energy: evolution and objectives* } \\
\hline & $1970^{\circ}$ & 1974 & 1980 & 1981 & Plan 1990 \\
\hline \multirow{6}{*}{$\begin{array}{l}\text { Coal } \\
\text { Petrol } \\
\text { Gas } \\
\text { Hydroelectrics } \\
\text { New energies } \\
\text { Nuclear }\end{array}$} & 38.1 & 31.6 & 34.0 & 33.5 & $35-40$ \\
\hline & 87.5 & 113.2 & 102.1 & 93.0 & $70-75$ \\
\hline & 9.3 & 16.0 & 23.6 & 24.6 & $31-40$ \\
\hline & 12.4 & 12.5 & 16.0 & 15.0 & $14-15$ \\
\hline & 2.0 & 2.1 & 3.2 & 3.4 & $10-14$ \\
\hline & 1.2 & 3.1 & 12.9 & 19.5 & $60-66$ \\
\hline \multirow{3}{*}{$\begin{array}{l}\text { Total } \\
\text { Proportion from } \\
\quad \text { indigenous sources }(\%)\end{array}$} & 150.5 & 178.5 & 191.8 & 189 & 232 \\
\hline & & & & & \\
\hline & 65.6 & 75.0 & 71.0 & 68.0 & $45-50$ \\
\hline
\end{tabular}

*Values are in million tonnes of oil equivalent

is now part of the government club and must be expected to obey the rules. And from the alternative energy point of view, here is a man who is a passionate and serious advocate of such forms of energy who must now turn his dreams into reality. If they work, well, that means more energy for France.

In fact the government's energy plans for the next decade are extraordinarily ambitious both in respect of their nuclear component and their renewables (see table). The energy supply from renewables - such as solar power and biomass - is expected at least to treble by 1990 compared with 1981 , and M. Rolant will be presiding over that growth. Rolant will have available to him COMES, the commission for solar energy, and the AEE, the agency for energy saving, which will be formed into a new organization whose exact definition and scale have yet cash will not be known until mid-1982

No doubt Rolant will have considerable influence on this, and perhaps his agricultural background will influence him (his colleagues at CFDT deny it); but it has been clear for some time that in renewables France is concentrating on the conversion of biomass. Of the 10-14 million tonnes of oil equivalent expected from renewables in 1990, half will come directly from the use of wood, and a further 2 million tonnes of oil equivalent from wastes. Surprisingly, however, of FF 35.2 million ( $£ 3.5$ million) research ministry funds available for renewables research in 1981, only FF 0.2 million $(£ 20,000)$ went to support biomass research. The largest sum (around half) went to coal. COMES spent FF 50 million ( $£ 5$ million) on biomass development in 1981 , but only a small fraction of that went on basic research. This may change. 